\title{
Oxidative stress-induced inhibition of adrenal steroidogenesis requires participation of p38 mitogen-activated protein kinase signaling pathway
}

\author{
Parveen Abidi ${ }^{1}$, Haiyan Zhang ${ }^{1}$, Syed M Zaidi ${ }^{1}$, Wen-Jun Shen ${ }^{1}$, Susan Leers-Sucheta ${ }^{1}$, Yuan Cortez ${ }^{1}$, \\ Jiahuai Han $^{3}$ and Salman Azhar ${ }^{1,2}$ \\ ${ }^{1}$ Department of Veterans Affairs Palo Alto Health Care System, Geriatric Research, Education and Clinical Center (GRECC), 3801 Miranda Avenue, Palo Alto, \\ California 94304, USA \\ ${ }^{2}$ Division of Gastroenterology and Hepatology, Department of Medicine, Stanford University, Stanford, California 94305, USA \\ ${ }^{3}$ Department of Immunology, The Scripps Research Institute, La Jolla, California 92037, USA \\ (Correspondence should be addressed to S Azhar at VA Palo Alto Health Care System; Email: salman.azhar@va.gov)
}

(S Leers-Sucheta is now at Pfizer Animal Health, Veterinary Medicine R \& D, Pfizer Inc., 7000 Portage Road, Kalamazoo, Michigan 49001, USA)

\begin{abstract}
Previous studies from this laboratory identified excessive oxidative stress as an important mediator of age-related decline in steroid hormone production. Here, we investigated whether oxidative stress exerts its antisteroidogenic action through modulation of oxidant-sensitive mitogen-activated protein kinase (MAPK) signaling pathways. To accomplish these studies, we employed a highly responsive mouse adrenocortical cell line, Y1-BS1 cells that secrete large quantities of steroids when stimulated with lipoprotein plus hormone. Treatment of these cells with superoxide, $\mathrm{H}_{2} \mathrm{O}_{2}$ or 4-hydroxy-2-nonenal (HNE) significantly inhibited steroid production and increased phosphorylation and activation of p38 MAPK. None of the treatments altered the phosphorylation of either extracellular signal-regulated kinases or c-Jun $\mathrm{N}$-terminal kinases (JNKs). Pretreatment of Y1-BS1 cells with MnTMPyP, a cell-permeable superoxide-dismutase/ catalase mimetic reactive oxygen species (ROS scavenger), completely prevented the superoxide- and $\mathrm{H}_{2} \mathrm{O}_{2}$-mediated inhibition of steroid production. Likewise, antioxidant $\mathrm{N}$-acetylcysteine completely blocked the HNE-induced loss of steroidogenic response. Incubation of Y1-BS1 cells with either MnTMPyP or NAC also upregulated $\mathrm{Bt}_{2} \mathrm{CAMP}$ and
\end{abstract}

$\mathrm{Bt}_{2} \mathrm{cAMP}+\mathrm{hHDL}_{3}$-stimulated steroid synthesis, indicating that endogenously produced ROS can inhibit steroidogenesis. Inhibition of p38 MAPK with SB203580 or SB202190 upregulated the basal steroid production and also prevented the oxidant-mediated inhibition of steroid production. mRNA measurements by qPCR indicated that Y1-BS1 adrenal cells predominantly express p38 MAPK $\alpha$ isoform, along with relatively low-level expression of p38 MAPK $\gamma$. By contrast, little or no expression was detected for $\mathrm{p} 38$ MAPK $\beta$ and $\mathrm{p} 38$ MAPK $\delta$ isoforms in these cells. Transfection of Y1BS1 cells with either caMKK3 or caMMK6 construct, the upstream p38 MAPK activators, decreased steroidogenesis, whereas transfection with dnMKK3 or dnMKK6 plasmid DNA increased steroidogenesis. Similarly, transfection of cells with a dnp38 MAPK $\alpha$ or $\operatorname{dnp} 38$ MAPK $\beta$ construct also increased steroid hormone production; however, the effect was less pronounced after expression of either dnp 38 MAPK $\gamma$ or dnp38 MAPK $\delta$ construct. These results indicate that activated p38 MAPK mediates oxidant (excessive oxidative stress)-induced inhibition of adrenal steroidogenesis.

Journal of Endocrinology (2008) 198, 193-207

\section{Introduction}

Advancing age in humans (Shifren \& Schiff 2000, Burger et al. 2002, Arlt 2004, Dharia \& Parker 2004, Harman 2005, Kaufman \& Vermeulen 2005) and experimental animals (Zirkin \& Chen 2000, Medicherla et al. 2002, Wang \& Stocco $2005)$ is associated with profound changes in the synthesis and secretion of steroid hormones. In rats, this steroidogenic decline is found in adrenocortical (Malamed \& Carsia 1983, Popplewell et al. 1986, Cheng et al. 1990) and testicular
Leydig cells (Bethea \& Walker 1979, Tsitouras et al. 1979, Liao et al. 1993, Chen et al. 1994) of several strains and is a progressive defect increasing in impact as the rat ages from 5 months to 12, 18, and 24 months (Malamed \& Carsia 1983, Popplewell et al. 1986, Liao et al. 1993, Medicherla et al. 2002). The major functional alteration occurs distal to sites of tropic hormone interaction and cAMP generation (Tsitouras et al. 1979, Popplewell et al. 1986, Liao et al. 1993) and is primarily related to a defect in the transport of free cholesterol to CYP11A1 ( $\left.\mathrm{P} 450_{\mathrm{scc}}\right)$ sites within the mitochondria where 
the conversion of cholesterol to pregnenolone (parent steroid) begins with side-chain cleavage (Popplewell \& Azhar 1987, Liao et al. 1993).

Although the cellular and molecular mechanisms controlling this aging defect (i.e. impaired cholesterol transport to mitochondria) have not been completely defined, considerable evidence from this laboratory points to excessive free radical formation and oxidative damage (especially from lifelong continued processing of cholesterol for steroid production (Azhar et al. 1995, Hanukoglu 2006)) to the cell machinery regulating the functional expression of key proteins involved in mitochondrial cholesterol transport (Azhar et al. 1995, Leers-Sucheta et al. 1999, Abidi et al. 2004, Cao et al. 2004). For example, previous studies from this laboratory have shown that age-induced loss of steroidogenic function is accompanied by a significant alteration in oxidative status of rat adrenal and testicular tissues including enhanced oxidative stress, loss of enzymatic and nonenzymatic antioxidants and increased membrane lipid peroxidation (Azhar et al. 1995, Cao et al. 2004). In addition, there is evidence that aging leads to alterations in the expression of two oxidant-sensitive transcription factors, AP-1 and NF- $\kappa$ B (Medicherla et al. 2001, 2002). Additional studies further demonstrated that expression of two cellular cholesterol transport/delivery proteins, StAR (Stocco \& Clark 1996) and peripheral-type benzodiazepine receptor (PBR) (now renamed translocator protein $(18 \mathrm{kDa})$ (TSPO) (Papadopoulos et al. 2006)), that assist in the intracellular delivery of cholesterol to mitochondrial CYP11A1 are also reduced during aging (Leers-Sucheta et al. 1999, Luo et al. 2001, Culty et al. 2002). However, the underlying mechanism(s) by which excessive oxidative stress leads to loss of steroid production during aging remain unclear. Oxidative stress has been implicated in the development of various pathophysiological changes that occur during aging. One important consequence of oxidative stress is the altered phosphorylation and activation of MAP kinases (Lewis et al. 1998, Martindale \& Holbrook 2002, Matsuzawa \& Ichijo 2005, McCubrey et al. 2006).

Mitogen-activated protein kinase (MAPK) signal transduction pathways are well-characterized signaling networks that regulate a variety of cellular processes including gene transcription, protein synthesis, cell cycle, apoptosis, cell differentiation, inflammation, and cytoskeletal rearrangements (Lewis et al. 1998, Widmann et al. 1999, Kyriakis \& Avruch 2001, Edmunds \& Mahadevan 2004, Raman et al. 2007, Whitmarsh 2007). MAPK signaling pathways can be triggered by a variety of stimuli including growth factors, cytokines, oxidative stress, environmental stress, and toxic chemical insults (Lewis et al. 1998, Martindale \& Holbrook 2002, Matsuzawa \& Ichijo 2005, McCubrey et al. 2006). There are three major groups of MAPKs: extracellular signalregulated kinase $(\mathrm{ERK}) 1 / 2$, p38 $(\alpha / \beta / \gamma / \delta)$, and $c-J u n$ N-terminal kinase (JNK1/2/3) (Widmann et al. 1999, Kyriakis \& Avruch 2001, Raman et al. 2007). These serine/ threonine kinases are phosphorylated/activated by distinct upstream dual specificity MAP kinases (MKKs or MEKs), which selectively target ERK (MKK1/2), JNK (MKK4/7), and p38 (MKK3/6) and phosphorylate both threonine and tyrosine in a regulatory $\mathrm{T}-\mathrm{X}-\mathrm{Y}$ motif present in all MAPKs (Widmann et al. 1999, Kyriakis \& Avruch 2001, Raman et al. 2007). Once activated, MAPKs can be translocated to the nucleus and regulate gene expression at transcriptional, translational, and posttranslational levels. Presently it is believed that growth and differentiation factors preferentially activate ERK signaling pathway, whereas the JNK and p38 pathways are more responsive to environmental and physiochemical stresses.

It is well documented that StAR protein (presumably in cooperation with PBRT/TSPO) plays a major role in steroid hormone synthesis by enhancing the translocation of cholesterol substrate from the outer to inner mitochondrial membranes, where the cholesterol side-chain cleavage

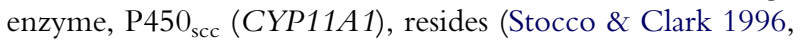
Stocco 2000). The regulation of StAR protein is executed primarily at the transcription level (Manna et al. 2003, 2004, Hiroi et al. 2004, Clem \& Clark 2006, Manna \& Stocco 2007), but posttranscriptional (phosphorylation) modification of StAR also plays a significant role in its functional expression (Stocco \& Clark 1996). Transcriptional regulations of StAR have been extensively studied, and a cluster of transcription factors is involved in the regulatory process (Manna et al. 2003, 2004, Hiroi et al. 2004, Clem \& Clark 2006, Manna \& Stocco 2007). One of these transcription factors is AP-1, a dimeric complex composed primarily of the Fos and Jun family of proteins (Chinenov \& Kerppola 2001, Hess et al. 2004), which play a critical role in the regulation of StAR gene transcription (Manna et al. 2004). Since CRE2 site overlaps with AP-1 site in the proximal StAR promoter region, its activity is also subject to regulation via the crosstalk between CREB and Fos/Jun proteins (Manna et al. 2004, Manna \& Stocco 2007). Interestingly, studies on the transcriptional regulation of another cholesterol transport protein, PBR/TSPO (which is believed to work in concert with StAR (Miller 2007, Papadopoulos et al. 2007)), have also identified an AP-1 binding site in its proximal promoter region (Giatzakis et al. 2007). Given the oxidant-sensitive nature of AP-1 (Dalton et al. 1999, Klaunig \& Kamendulis 2004), involvement of stress-activated kinases, the MAPKs, in the regulation of AP-1 (Whitmarsh \& Davis 1996, Pramanik et al. 2003, Tanos et al. 2005, Humar et al. 2007, Whitmarsh 2007) and the fact that functional expression of AP-1 is substantially reduced (Medicherla et al. 2001), while p38 MAPK is specifically activated in intact rat adrenal glands (Abidi et al. 2008) and Leydig cells (unpublished observations) during aging, it seems likely that oxidant stressors acting on p38 MAPK and AP-1 contribute to the age-related decline in StAR (and PBR/TSPO) expression and subsequently loss of steroidogenic function.

The present studies were initiated to further expand on the observations that p38 MAPK is specifically activated in intact rat adrenal glands (Abidi et al. 2008) and testicular Leydig cells 
(unpublished observations) during aging and to critically evaluate whether excessive oxidative stress-induced inhibition of steroid synthesis is dependent upon activation of $\mathrm{p} 38$ MAPK. These studies were conducted using mouse hormone- and lipoprotein-sensitive adrenocortical cell line Y1-BS1 as an in vitro adrenal model system. Our data indicate that exposure of cells to oxidants leads to a significant reduction in hormone-stimulated steroid secretion, providing a direct demonstration that oxidative stress negatively impacts steroidogenesis. We also present data showing that both pharmacological and molecular inhibitors of p38 MAPK attenuate oxidant-dependent inhibition of steroid secretion, demonstrating that oxidative stress-mediated suppression of steroidogenesis is mediated through activation of p38 MAPK. These results define a novel mechanism for oxidative stressmediated inhibition of steroid synthesis and identify p38 MAPK activation as a signaling pathway mediating oxidative stress-induced inhibition of steroidogenesis.

\section{Materials and Methods}

\section{Reagents and antibodies}

The following chemicals were purchased from Calbiochem (La Jolla, CA, USA): MEK/ERK inhibitors PD098059 and U0126, the p38 MAP kinase inhibitors SB203580, SB202190, and SB202474 (inactive analog), the JNK inhibitor SP600125, MnTMPyP (Mn(III)tetrakis(1-methyl4-pyridyl)porphyrin pentachloride), and MnTBAP (Mn(III)tetrakis(4-benzoic acid)porphyrin). $\mathrm{Bt}_{2} \mathrm{cAMP}$, fatty acid poor BSA, hydrogen peroxide $\left(\mathrm{H}_{2} \mathrm{O}_{2}\right), \mathrm{N}$-acetylcysteine (NAC), xanthine and xanthine oxidase were supplied by Sigma-Aldrich. 4-Hydroxy-2-nonenal (HNE) was purchased from Cayman Chemical Co. (Ann Arbor, MI, USA), and 6-carboxy-2 $2^{\prime} 7^{\prime}$-dichlorodihydrofluorescein diacetate (DCFDA) was obtained from Molecular Probes/Invitrogen Corporation. All other reagents used were of analytical grade. Polyclonal antibodies against total ERK1/ERK2, JNK1/JNK2, and p38 MAPK $\alpha$ were purchased from Cell Signaling Technology (Beverly, MA, USA). Phospho-specific antibodies that recognize ERKs phosphorylated at $\mathrm{Thr}^{202}$ and $\mathrm{Tyr}^{204}$, and $\mathrm{p} 38$ MAPK phosphorylated at $\mathrm{Thr}^{180}$ and $\mathrm{Tyr}^{182}$ were also supplied by Cell Signaling Technology. PhosphoJNKs $\left(\mathrm{Thr}^{183}\right.$ and $\mathrm{Tyr}^{185}$ ) antibody was obtained from Santa Cruz Biotechnology, Inc. (Santa Cruz, CA, USA). Anti-myc and anti-FLAG M2 monoclonal antibodies were purchased from Sigma-Aldrich.

\section{Plasmids}

Expression vectors of wild-type human FLAG-MKK3, constitutively active human FLAG-MKK3(Glu) $\left(\mathrm{Ser}^{189} \rightarrow\right.$ Glu/Thr $\left.{ }^{193} \rightarrow \mathrm{Glu}\right)$, dominant-negative human FLAG MKK3(Ala) $\left(\mathrm{Ser}^{189} \rightarrow \mathrm{Ala} / \mathrm{Thr}^{193} \rightarrow \mathrm{Ala}\right)$, wild-type human FLAG-MKK6, constitutively active human FLAG
MKK6(Glu) $\quad\left(\mathrm{Ser}^{207} \rightarrow \mathrm{Glu} / \mathrm{Thr}^{221} \rightarrow \mathrm{Glu}\right)$, and dominantnegative human FLAG MKK6(K82A) $\left(\mathrm{Lys}^{82} \rightarrow \mathrm{Ala}\right)$, were generously provided by Dr Roger Davis, University of Massachusetts Medical School, Worcester, MA, USA (Raingeaud et al. 1996). Wild-type myc-tagged human MKK7, constitutively active myc-tagged human MKK7(MKK73E) $\left(\mathrm{Ser}^{271} \rightarrow \mathrm{Glu} / \mathrm{Thr}^{275} \rightarrow \mathrm{Glu} / \mathrm{Ser}^{277} \rightarrow \mathrm{Glu}\right), \quad$ dominantnegative mutant form of MKK7(MKK73A) (Ser ${ }^{271} \rightarrow \mathrm{Ala} /$ $\mathrm{Thr}^{275} \rightarrow \mathrm{Ala} / \mathrm{Ser}^{277} \rightarrow \mathrm{Ala}$ ), and dominant-negative (kinasedead) mutant form of MKK7(MKK7K149M) (Lys ${ }^{149} \rightarrow$ Met) were kindly provided by Dr Michael Kracht, Medical School, Hannover, Germany (Holtmann et al. 1999). The cloning of wild-type FLAG-tagged p38 $\alpha$, p38 $\beta$, p38 $\gamma$, and p38 MAPK constructs have been described previously (Pramanik et al. 2003). Dominant-negative mutant forms of FLAG-tagged human $\mathrm{p} 38 \alpha(\mathrm{AF})\left(\mathrm{Thr}^{180} \rightarrow \mathrm{Ala} / \mathrm{Tyr}^{182} \rightarrow \mathrm{Phe}\right), \mathrm{p} 38 \beta(\mathrm{AF})$ $\left(\mathrm{Thr}^{188} \rightarrow \mathrm{Ala} / \mathrm{Tyr}^{190} \rightarrow \mathrm{Phe}\right), \mathrm{p} 38 \gamma \quad(\mathrm{AF}) \quad\left(\mathrm{Thr}^{183} \rightarrow \mathrm{Ala} /\right.$ $\left.\mathrm{Tyr}^{185} \rightarrow \mathrm{Phe}\right)$, and $\mathrm{p} 38 \delta(\mathrm{AF})\left(\mathrm{Thr}^{180} \rightarrow \mathrm{Ala} / \mathrm{Tyr}^{182} \rightarrow \mathrm{Phe}\right)$ were created by substituting threonine and tyrosine with alanine and phenylalanine respectively in TGY motif (Pramanik et al. 2003).

Culture and treatment of Y1-BS1 mouse adrenocortical cells with oxidants, and/or antioxidants

The Y1-BS1 mouse adrenocortical cell line was initially obtained from Dr David William's laboratory (State University at Stony Brook, Stony Brook, NY, USA) in 1998. The cells were grown in F-10 medium supplemented with $12 \cdot 5 \%$ horse serum, $2 \cdot 5 \%$ fetal bovine serum, $2 \mathrm{mM}$ glutamine, 100 units $/ \mathrm{ml}$ penicillin, and $100 \mu \mathrm{g} / \mathrm{ml}$ streptomycin at $37^{\circ} \mathrm{C}$ under $5 \% \mathrm{CO}_{2}$.

To induce oxidative stress, cells cultured in $60 \mathrm{~mm}$ dishes were treated with xanthine $(0.25 \mathrm{mM})+$ xanthine oxidase $(20 \mathrm{mU} / \mathrm{ml})$ (to generate a flux of superoxide anion, $\mathrm{O}_{2}^{--}$, and $\left.\mathrm{H}_{2} \mathrm{O}_{2}\right), \mathrm{H}_{2} \mathrm{O}_{2}(0 \cdot 05,0 \cdot 1,0 \cdot 25,0 \cdot 5$, or $1 \cdot 0 \mathrm{mM})$ or a lipid peroxidation product, $\operatorname{HNE}(10,20,50$, or $100 \mu \mathrm{M})$ for an appropriate time as specified under each figure and table. In other experiments, cells were co-incubated with xanthine $(0.25 \mathrm{mM})+$ xanthine oxidase $(20 \mathrm{mU} / \mathrm{ml}) \pm$ the superoxide-dismutase (SOD)/catalase mimetic MnTMPyP $(10 \mu \mathrm{M})$, $\mathrm{H}_{2} \mathrm{O}_{2}(0 \cdot 1 \mathrm{mM}) \pm \mathrm{MnTMPyP}(10 \mu \mathrm{M})$, or HNE $(50 \mu \mathrm{M}) \pm$ antioxidant NAC (20 mM) for $1 \mathrm{~h}$. Following treatment, cell samples were washed and were either used immediately for the measurement of steroid hormone secretion or stored frozen until analyzed for total and phosphorylated forms of ERK1/ERK2, p38 MAPK, and JNK1/JNK2. Cell viability was assessed by following the conversion of MTT (3-(4,5dimethyl-thiazol-2-yl)-2,5-diphenyltetrazolium bromide) to formazan crystals (Mosmann 1983), a reaction dependent upon mitochondrial respiratory chain activity that reflects mitochondrial redox state. After treatment with oxidants and washing, an MTT solution was added to the dishes at a final concentration of $500 \mu \mathrm{g} / \mathrm{ml}$ and the induction continued at $37^{\circ} \mathrm{C}$ for $3 \mathrm{~h}$. Following incubation, the medium was aspirated and accumulated formazan product was solubilized 
with 1:1 solution of dimethyl sulfoxide/absolute ethanol. Cell viability was determined by the differences in absorbance at wavelength $570 \mathrm{~nm}$ minus $690 \mathrm{~nm}$ using a microplate reader.

\section{Measurement of ROS}

Oxidant-induced intracellular reactive oxygen species (ROS) generation and oxidative stress was monitored by measuring changes in fluorescence resulting from intracellular oxidation of $2^{\prime} 7^{\prime}$-dichlorofluorescein (DCFH) (Keller et al. 2004). The probe DCFDA enters the cell, is hydrolyzed by cellular esterases, where upon nonfluorescent DCFH is trapped inside the cell. Subsequent oxidation by ROS yields DCF. Y1-BS1 cells grown in $35 \mathrm{~mm}$ dishes were pre-loaded with DCFDA $(10 \mu \mathrm{M})$ for $60 \mathrm{~min}$, washed and further incubated with buffer alone (control), xanthine (X, $0.25 \mathrm{mM})+$ xanthine oxidase (XO, $20 \mathrm{mU} / \mathrm{ml}), \mathrm{H}_{2} \mathrm{O}_{2}(100 \mu \mathrm{M})$, or $\mathrm{HNE}(50 \mu \mathrm{M})$ in the presence of $\mathrm{Bt}_{2} \mathrm{CAMP}(2.5 \mathrm{mM})$ for $1 \mathrm{~h}$. At the end of incubation the media were removed and cells were immediately lysed and centrifuged. DCF fluorescence of the cell lysates was measured using a microplate reader with an excitation wavelength of $488 \mathrm{~nm}$ and emission wavelength of $515 \mathrm{~nm}$. Results are expressed as percent change from medium-treated controls.

\section{Transfection of Y1-BS1 adrenocortical cells}

For transient transfection experiments, Y1-BS1 cells were sub-cultured at a density of $1.5 \times 10^{5}$ cells/dish in $60 \mathrm{~mm}$ tissue culture dishes the day prior to transfection. Each plate was transfected with $5 \mu \mathrm{g}$ vector alone or various MAPK constructs as noted under specific tables and figures using a FuGENE transfection reagent according to the manufacturer's instructions (Roche Molecular Diagnostics). After $48 \mathrm{~h}$ of transfection, cells were utilized for various measurements.

\section{Measurement of steroid secretion by Y1-BS1 mouse adrenocortical cells}

To examine hormone-stimulated and lipoprotein-supported steroid production, native Y1-BS1 cells, oxidant/antioxidanttreated Y1-BS1 cells, or Y1-BS1 cells transiently transfected with various MAPK constructs were incubated for $5 \mathrm{~h}$ with $\mathrm{Bt}_{2} \mathrm{cAMP}(2.5 \mathrm{mM}) \pm \mathrm{hHDL}_{3}(500 \mu \mathrm{g} / \mathrm{ml})$, and following incubation the media were collected and stored frozen until analyzed. Steroids were extracted from the medium using methylene chloride and quantified by fluorescence in $65 \%$ sulfuric acid-35\% ethanol using $20 \alpha$-dihydroprogesterone as a standard.

To evaluate the ability of MAPKs to modulate hormonestimulated and lipoprotein-supported steroidogenesis, we utilized the specific MEK/ERK inhibitors PD098059 and U0126, the p38 MAP kinase inhibitors SB203580, SB202190, and SB202474 (inactive analog), and the JNK inhibitor SP600125. Triplicate dishes of Y1-BS1 cells were pretreated with vehicle alone (control), PD098059 $(30 \mu \mathrm{M})$, U0126 $(10 \mu \mathrm{M})$, SB203580 $(10 \mu \mathrm{M})$, SB202190 $(10 \mu \mathrm{M})$, SB202474 $(10 \mu \mathrm{M})$, or SP600125 $(10 \mu \mathrm{M})$ for $1 \mathrm{~h}$, and incubations continued for an additional $5 \mathrm{~h}$ following the addition of $\mathrm{Bt}_{2} \mathrm{cAMP} \pm \mathrm{hHDL}_{3}(500 \mu \mathrm{g}$ protein $/ \mathrm{ml})$. At the end of incubation, the media were collected, frozen, and stored frozen until analyzed for $20 \alpha$-dihydroprogesterone levels as described above. Cell viability after treatment was monitored using the MTT assay as described above.

\section{Preparation of lipoproteins}

Human low-density lipoprotein (hLDL) and human apoEfree high-density lipoproteins ${ }_{3}\left(\mathrm{hHDL}_{3}\right)$ were isolated and characterized as previously described (Reaven et al. 1990).

Western blot analysis of total and phosphorylated forms of ERKs, p38 MAPK, and JNKs

The Y1-BS1 adrenal cell samples were solubilized with lysis buffer (20 mM HEPES (pH 7-4), 1\% Triton X-100 (vol/vol), $150 \mathrm{mM} \mathrm{NaCl}, 1 \mathrm{mM}$ EDTA, $1 \mathrm{mM}$ EGTA, $20 \mathrm{mM} \mathrm{NaF}$, $20 \mathrm{mM} \beta$-glycerophosphate, $10 \mathrm{mM}$ sodium pyrophosphate, $1 \mathrm{mM}$ sodium vanadate, $10 \mathrm{nM}$ okadaic acid, $1 \mathrm{mM}$ dithiothreitol, $10 \mu \mathrm{g} / \mathrm{ml}$ leupeptin, $10 \mu \mathrm{g} / \mathrm{ml}$ pepstatin, $10 \mu \mathrm{g} / \mathrm{ml}$ aprotinin, $0 \cdot 5 \mathrm{mM}$ 4-(2-aminoethyl)benzylsulfonyl fluoride, $10 \mu \mathrm{M} \mathrm{E}-64,50 \mu \mathrm{M}$ bestatin, $10 \mu \mathrm{g} / \mathrm{ml}$ tosyl-Lphenylalanine chloromethyl ketone and $10 \mathrm{mg} / \mathrm{ml} \mathrm{N}^{\alpha}$-tosylL-lysine chloromethyl ketone) and incubated for $15 \mathrm{~min}$ at $4{ }^{\circ} \mathrm{C}$. Subsequently, each cell lysate was sonicated briefly to disrupt chromatin (DNA), centrifuged at $15000 \mathrm{~g}$ for $10 \mathrm{~min}$ at $4{ }^{\circ} \mathrm{C}$ and protein concentration of each clarified lysate was determined. All cell lysate samples were stored frozen until analyzed by western blotting (Kelley et al. 2004).

Samples containing an equal amount of protein $(30-40 \mu \mathrm{g})$ were fractionated by SDS-PAGE (10\% polyacrylamide gel with $4 \%$ stacking gel) and transferred to Immobilon polyvinylidene difluoride membrane (Millipore Corp., Bedford, MA, USA). After transfer, the membrane was washed in TBS containing $0 \cdot 1 \%$ Tween 20 (TBS) and incubated in blocking buffer (TTBS containing 5\% nonfat dry milk) for $90 \mathrm{~min}$ at room temperature, followed by overnight incubation at $4{ }^{\circ} \mathrm{C}$ with the primary antibody in blocking buffer (against total or phosphorylated forms of ERK1/ERK2, p38 MAPK, or JNK1/JNK2, or anti-FLAG monoclonal antibody). Subsequently, the membrane was washed in TTBS and incubated for $2 \mathrm{~h}$ with horseradish peroxidase-conjugated anti-rabbit or anti-mouse $\operatorname{IgG}$ in blocking buffer. The immunoreactive bands were then visualized using a LumiGLO Chemiluminescent Detection System (Kirkegaard and Perry Laboratories Inc., Gaithersburg, MD, USA) followed by exposure to X-ray film $(10-30 \mathrm{~min})$ and quantified by Fluor-S-MultiImager scanning densitometry system (Bio-Rad). 
Determination of $38 \mathrm{MAPK}$ activity by western blotting

The activity of p38 MAPK was determined using a kit supplied by Cell Signaling Technology (catalog \#9820). Briefly, cell lysates were incubated cold overnight with an immobilized primary phospho-p38 MAPK $\left(\mathrm{Thr}^{180} / \mathrm{Tyr}^{182}\right.$ ) monoclonal primary antibody to selectively immunoprecipitate active p38 MAPK. Subsequently, immobilized immunoprecipitates were incubated in a buffer supplemented with ATP $(200 \mu \mathrm{M})$ and ATF-2 fusion protein. The reactions were terminated by the addition of a $3 \times$ SDS sample buffer and subjected to SDS-PAGE followed by western blotting. The blots were developed with a polyclonal phospho-ATF-2 $\left(\mathrm{Thr}^{71}\right.$ ) antibody and HRP-linked anti-rabbit IgG and if necessary, signals were quantified by the Fluor-S-MultiImager scanning densitometry system (Bio-Rad).

\section{$R N A$ isolation}

Total RNA was isolated from young and old Leydig cells (preincubated with or without $10 \mathrm{ng} / \mathrm{ml}$ hCG) using TRIzol (Invitrogen Life Technologies) according to the manufacturer's protocol. The purity and concentration of RNA samples were determined by following absorbance $\left(\mathrm{A}_{260} / \mathrm{A}_{280}\right)$ ratios. The integrity of the purified RNA samples was confirmed by $1 \cdot 2 \%$ formaldehyde-agarose gel electrophoresis.

\section{Measurement of $m R N A$ levels by quantitative PCR (qPCR)}

The specific primer sets used to detect the mRNA expression of p38 MAPK $\alpha$, p38 MAPK $\beta$, p38 MAPK $\gamma$ and p38 MAPK $\delta$ were developed using Primer Express software (Applied Biosystems, Foster City, CA, USA) according to the recommended guidelines based on the sequences accessed through GenBank. Table 1 shows the primer sequences for qPCR assay used. First-strand cDNA was synthesized from $2 \mu \mathrm{g}$ total RNA by incubating for $1 \mathrm{~h}$ at $50{ }^{\circ} \mathrm{C}$ with SuperScript II reverse transcriptase (Invitrogen Life Technologies) and random primers. Amplification of cDNAs was performed with an ABI Prism 7900 system according to the manufacturer's instructions. Each sample consisted of $1 \mu \mathrm{l}$ cDNA, $4 \mathrm{mM} \mathrm{MgCl}_{2}, 0.2 \mathrm{mM}$ deoxynucleoside triphosphate, $500 \mathrm{nM}$ of each sense and antisense primer, $2 \mu 110 \times$ PCR buffer, TaqMan polymerase, and SYBR Green master mix in a final volume of $20 \mu \mathrm{l}$. As an internal quantitative control for gene expression, ribosomal protein 36B4 gene expression was also determined. Real-time PCR was performed with an ABI Prism. The relative mass of p38 MAPK $\alpha$, p38 MAPK $\beta$, p38 MAPK $\gamma$, p38 MAPK $\delta$, or 36B4 mRNA was calculated by the comparative cycle of threshold detection method according to the manufacturer's instruction. Three independent sets of Taqman real-time PCR were performed using different RNA preparations; each run of Taqman real-time PCR was conducted in triplicate. The final data were normalized to $36 \mathrm{~B} 4$ and the ratios of $\mathrm{p} 38 \mathrm{MAPK} \alpha$, p38 MAPK $\beta$, p38 MAPK $\gamma$ and p38 MAPK $\delta$ to 36B4 represented the normalized relative levels of each mRNA.

\section{Analytical procedures}

Protein was measured with a bicinchoninic acid protein assay kit (Pierce Chemical Co., Rockford, IL, USA). The procedure of Markwell et al. (1978) was used to quantify the protein content of $\mathrm{hHDL}_{3}$ and hLDL. Cholesterol content of $\mathrm{hHDL}_{3}$ and hLDL was determined according to the procedure of Tercyak (1991).

\section{Statistical analysis}

All results are expressed as mean \pm s.E.M. Data were analyzed using a nonpaired two-tailed Student's $t$-test using GraphPad Prism version 3.00 software for Windows (GraphPad Software, San Diego, CA, USA). Differences between groups was considered significant if $P<0 \cdot 05$.

\section{Results}

To investigate the molecular basis of the potential interaction between oxidative stress, p38 MAPK activation, and loss of steroidogenesis, we employed Y1-BS1 cells, a stable subclone of the Y1 mouse adrenocortical tumor cell line (Schimmer 1979). The Y1-BS1 cell line provides a useful in vitro model system for studying hormone-stimulated and lipoprotein-supported steroidogenesis (Faust et al. 1977, Rae et al. 1979, Temel et al. 1997). Unlike normal rodent adrenal cells that secrete corticosterone, Y1-BS1 cells chiefly secrete $20 \alpha$-dihydroprogesterone and $11 \beta$-hydroxy-20 $\alpha$-dihydroprogesterone.

Table 1 Mouse-specific primer pairs used for quantitative PCR (qPCR)

\begin{tabular}{|c|c|c|}
\hline \multirow[b]{2}{*}{ Gene } & Forward primer & Reverse primer \\
\hline & & \\
\hline p38 $\alpha$ & 5'-CCССАGAGATCATGCTGAAT-3' & 5'-ACAACGTTCTTCCGGTCAAC-3' \\
\hline p38 $\beta$ & 5'-ATGTAGCGGTGAACGAGGAC-3' & 5'-CCACATATCCGGTCATCTCC-3' \\
\hline 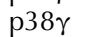 & $5^{\prime}$-GAGACTTGAAGCCTGGCAAC-3' & $5^{\prime}$-CCGGGTTACCACATATCCTG-3' \\
\hline p38ठ & $5^{\prime}$-CGCCACACAGACACTGAGAT-3' & $5^{\prime}$-ATGATGCAACCAACAGACCA-3' \\
\hline $36 B 4$ & $5^{\prime}$-CACTGGTCTAGGACCCGAGAAG-3' & $5^{\prime}$-GGTGCCTCTGGAGATTTTCG-3' \\
\hline
\end{tabular}


Effect of various additives on steroid production by Y1-BS1 cells

To examine the effects of hormones and exogenous cholesterol on steroid production, Y1-BS1 cells were incubated without (basal) or with adrenocorticotrophin (ACTH) or its second messenger analog, $\mathrm{Bt}_{2} \mathrm{CAMP} \pm \mathrm{LDL}$ or $\mathrm{HDL}$ for $5 \mathrm{~h}$ before harvesting aliquots of medium for quantification of the $20 \alpha-$ dihydroprogesterone content. As expected, both ACTH and $\mathrm{Bt}_{2} \mathrm{cAMP}$ treatment increased steroid production by $\sim 10-$ to 11-fold (Fig. 1). Incubation of Y1-BS1 cells with either hLDL or hHDL also significantly increased the production of $20 \alpha-$ dihydroprogesterone. Steroid production further enhanced after treatment with $\mathrm{ACTH}$ or $\mathrm{Bt}_{2} \mathrm{CAMP}+$ lipoprotein $(\mathrm{hLDL}$ or hHDL) (Fig. 1).

\section{Oxidant-mediated inhibition of steroidogenesis}

Next, we examined the inhibitory actions of enhanced oxidative stress on steroidogenesis. In the first set of experiments, we studied the effects of three oxidants, superoxide anion $\left(\mathrm{O}_{2}^{-}\right)$(Englert \& Shacter 2002), $\mathrm{H}_{2} \mathrm{O}_{2}$ (Nair et al. 2004), and HNE (Uchida et al. 1999) on steroid production in response to $\mathrm{Bt}_{2} \mathrm{cAMP}$ or $\mathrm{Bt}_{2} \mathrm{cAMP}+h \mathrm{HDL}_{3}$. $\mathrm{HNE}$, an end product of the lipid peroxidation of membraneassociated polyunsaturated fatty acids, exhibits high reactivity towards various macromolecules (Uchida 2000, Esterbauer et al. 1991). The results in Fig. 2 show that exposure of Y1$\mathrm{BS} 1$ cells to $\mathrm{O}_{2}^{--}$generated from xanthine oxidase $(\mathrm{XO})$ and xanthine $(\mathrm{X})$ significantly inhibited both $\mathrm{Bt}_{2} \mathrm{cAMP}$ and $\mathrm{Bt}_{2} \mathrm{cAMP}+\mathrm{hHDL}_{3}$-stimulated steroid synthesis. Likewise, treatment of cells with either $\mathrm{H}_{2} \mathrm{O}_{2}$ or HNE, an end product of lipid peroxidation (Uchida et al. 1999) also caused a reduction in 20 $\alpha$-dihydroprogesterone production in response to both $\mathrm{Bt}_{2} \mathrm{cAMP}$ alone and $\mathrm{Bt}_{2} \mathrm{cAMP}+\mathrm{hHDL}_{3}$
(Fig. 2). To ensure that the oxidants used to induce oxidative stress were indeed causing such an effect, simultaneous measurements of ROS production using DCFDA were performed during oxidant-induced oxidative stress. As shown in Fig. 3, the extent of DCF oxidation was significantly increased in cells treated with $\mathrm{H}_{2} \mathrm{O}_{2}$ or HNE. Relatively, very little fluorescence was noted in cells exposed to $\mathrm{X} / \mathrm{XO}$ (superoxide anion, $\mathrm{O}_{2}^{--}$); this is most likely due to the fact that $\mathrm{O}_{2}^{--}$reacts very poorly with the dye and the observed fluorescence represents only a fraction of the $\mathrm{O}_{2}^{--}$that reacted with $\mathrm{NO}$ to form peroxynitrite $(\mathrm{ONOO}-)$ or have been dismutated to $\mathrm{H}_{2} \mathrm{O}_{2}$ by cellular superoxide dismutases (SODs) (Keller et al. 2002). To rule out the possibility that oxidantinduced inhibition of steroidogenesis was due to increased cell death, cell viability was measured under identical experimental conditions using a sensitive MTT assay (Mosmann 1983). None of these three oxidants, however, had any significant effect on the cell viability, which remained in the range of $85-90 \%$ (data not shown).

To examine whether oxidants directly mediate inhibition of steroidogenesis, we measured $20 \alpha$-dihydroprogesterone production in the presence of ROS scavengers, manganese (III) tetrakis(1-methyl-4-pyridyl) porphyrin (MnTMPyP), and $\mathrm{N}$-acetyl cysteine (NAC). MnTMPyP functions as a cellpermeable SOD/catalase mimetic (Pimental et al. 2001), while antioxidant NAC is the precursor of cellular glutathione (Jonassen et al. 1999) and is known to interfere with HNE action (Uchida et al. 2004). As shown in Fig. 2, pretreatment of Y1-BS1 cells with MnTMPyP attenuated the X/XO- or $\mathrm{H}_{2} \mathrm{O}_{2}$-induced inhibition of steroid production. To address the possibility that MnTMPyP prevented the inhibition of steroidogenesis via a nonspecific effect, control experiments were conducted with light-inactivated, $\mathrm{Mn}(\mathrm{III})$ tetrakis (4-benzoic acid) porphyrin (MnTBAP). As expected,

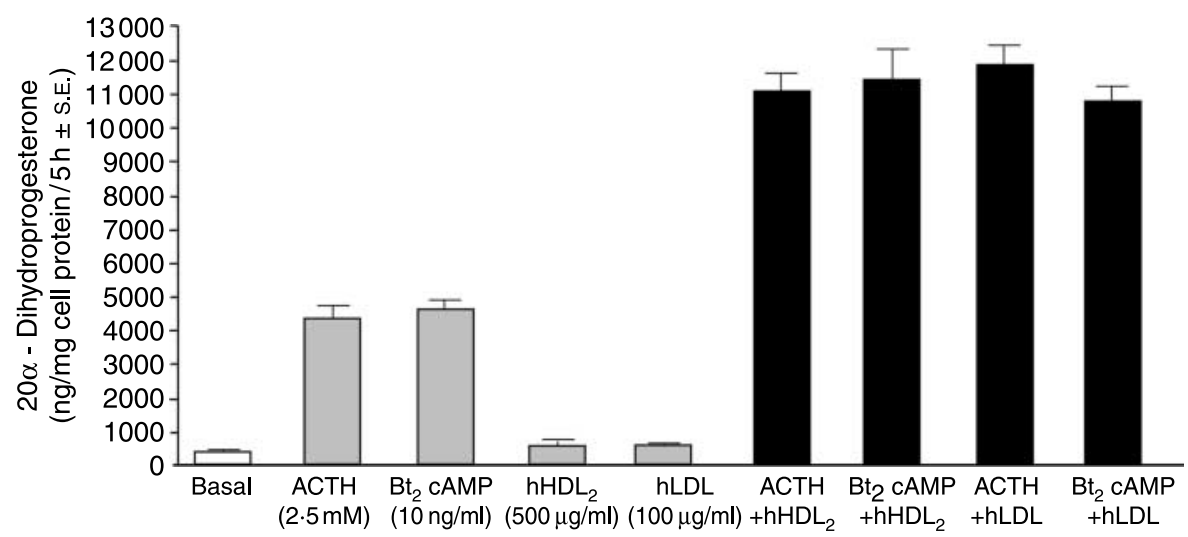

Figure $1 \mathrm{ACTH}$ - or $\mathrm{Bt}_{2} \mathrm{CAMP}$-stimulated and lipoprotein-supported steroid production by the $\mathrm{Y} 1-\mathrm{BS} 1$ mouse adrenocortical tumor cells. Results are mean \pm s.E.M. of three independent experiments. Y1-BS1 mouse adrenocortical tumor cells were incubated in a serum-free medium in the absence or presence of $\mathrm{ACTH}(10 \mathrm{ng} / \mathrm{ml}), \mathrm{Bt}_{2} \mathrm{CAMP}(2.5 \mathrm{mM}), \mathrm{hHDL}_{3}(500 \mu \mathrm{g}$ protein $/ \mathrm{ml}), \mathrm{hLDL}$ (100 $\mu$ g protein $\left./ \mathrm{ml}\right)$, or both ACTH $(10 \mathrm{ng} / \mathrm{ml})$ or Bt ${ }_{2} \mathrm{CAMP}(2.5 \mathrm{mM})$, and $\mathrm{hHDL}_{3}(500 \mu \mathrm{g}$ protein $/ \mathrm{ml})$ or hLDL $(100 \mu \mathrm{g}$ protein $/ \mathrm{ml}$ ) at $37^{\circ} \mathrm{C}$ for $5 \mathrm{~h}$. Following incubation, a suitable aliquot of the medium from each sample was collected and steroids were extracted from the medium using methylene chloride and quantified by fluorescence in $65 \%$ sulfuric acid-35\% ethanol using $20 \alpha$-dihydroprogesterone as standard. 

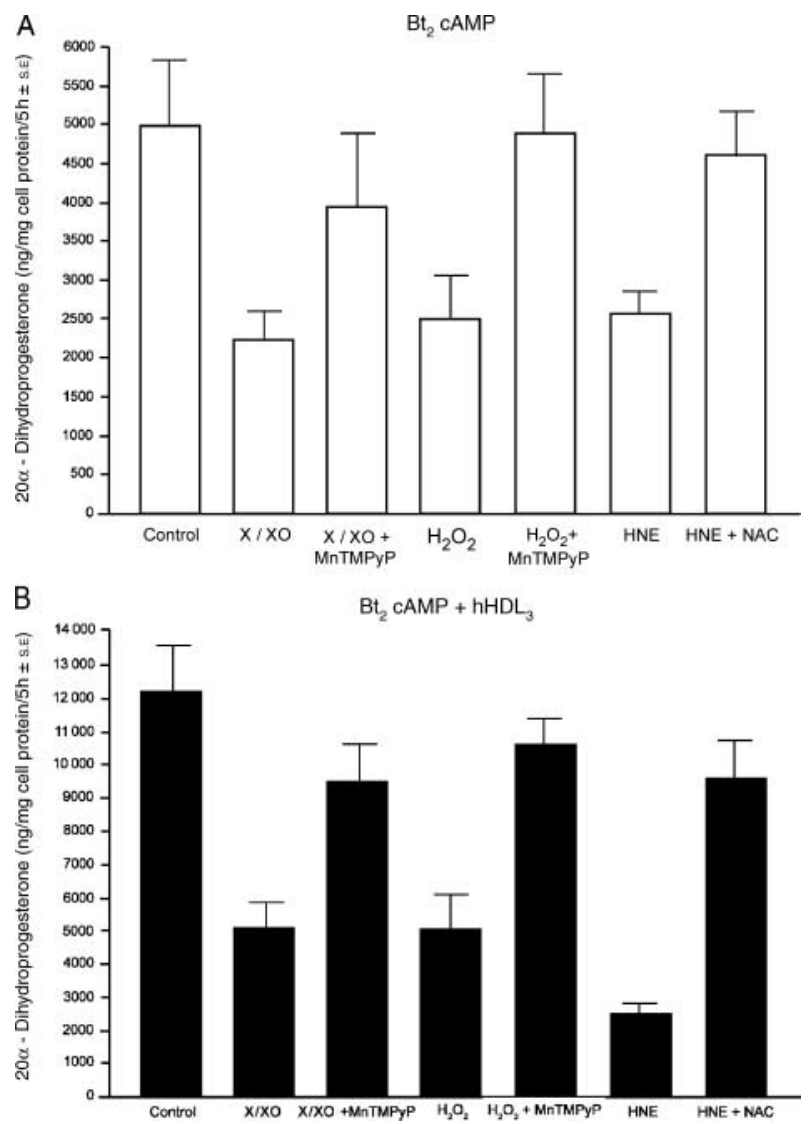

Figure 2 Effect of the ROS scavengers MnTMPyP and NAC on oxidant-mediated inhibition of adrenocortical cell steroidogenesis. Results are mean \pm S.E.M. of four independent experiments. (A) Y1BS1 cells cultured in $60 \mathrm{~mm}$ dishes were treated with xanthine $(0 \cdot 25 \mathrm{mM})+$ xanthine oxidase $(20 \mathrm{mU} / \mathrm{ml})$ (to generate a flux of superoxide anion, $\mathrm{O}_{2}^{--}$, and $\left.\mathrm{H}_{2} \mathrm{O}_{2}\right) \pm$ the superoxide-dismutase (SOD)/catalase mimetic MnTMPyP $(10 \mu \mathrm{M}), \mathrm{H}_{2} \mathrm{O}_{2}(0 \cdot 1 \mathrm{mM}) \pm$ $\operatorname{MnTMPyP}(10 \mu \mathrm{M})$, or a lipid peroxidation product, $\operatorname{HNE}(50 \mu \mathrm{M}) \pm$ antioxidant NAC $(20 \mathrm{mM})$ for $1 \mathrm{~h}$. Following treatment, dishes were rapidly washed and incubated with $\mathrm{Bt}_{2} \mathrm{CAMP}(2 \cdot 5 \mathrm{mM}) \pm \mathrm{hHDL}_{3}$ $(500 \mu \mathrm{g} / \mathrm{ml})$ for $5 \mathrm{~h}$. (B) Following incubation, media was collected and stored frozen until analyzed. Steroids were extracted from the medium using methylene chloride and quantified by fluorescence in $65 \%$ sulfuric acid-35\% ethanol using $20 \alpha$-dihydroprogesterone as a standard. The basal amount of $20 \alpha$-dihydroprogesterone produced was $32 \cdot 5 \pm 4 \cdot 6 \mathrm{ng} / \mathrm{mg}$ cell protein $/ 5 \mathrm{~h}$.

$\mathrm{X} / \mathrm{XO}$ - or $\mathrm{H}_{2} \mathrm{O}_{2}$-induced inhibition in $20 \alpha$-dihydroprogesterone production was unaffected in cells pretreated with light-inactivated MnTBAP (10 $\mu \mathrm{M}$; data not shown). The results of these experiments suggest that blockade of $\mathrm{X} / \mathrm{XO}-$ or $\mathrm{H}_{2} \mathrm{O}_{2}$-induced inhibition of steroidogenesis is not due to a nonspecific effect of MnTMPyP, but occurs in response to the scavenging of superoxide and $\mathrm{H}_{2} \mathrm{O}_{2}$ and suggest that these oxidants directly impair the steroidogenic function. In a similar manner, to investigate whether NAC could prevent an $\mathrm{HNE}$-induced reduction in steroid formation, cells were co-incubated with NAC \pm HNE. Addition of NAC to the incubation medium also effectively

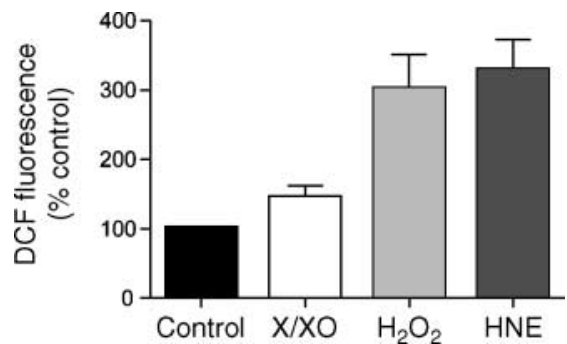

Figure 3 Oxidant-induced reactive oxygen species (ROS) production and oxidative stress in Y1-BS1 cells. Triplicate dishes of cultured Y1-BS1 adrenal cells were pre-loaded with $10 \mathrm{mM}$ 6-carboxy-2 $2^{\prime} 7^{\prime}$-dichlorodihydrofluorescein diacetate (DCFDA) for $60 \mathrm{~min}$. Subsequently, dishes were washed and incubated with in situ generated superoxide from xanthine $(0 \cdot 25 \mathrm{mM})+$ xanthine oxidase $(20 \mathrm{mU} / \mathrm{ml})$ (in situ generated superoxide), $\mathrm{H}_{2} \mathrm{O}_{2}(100 \mu \mathrm{M})$ or HNE $(50 \mu \mathrm{M})$ for $1 \mathrm{~h}$. At the end of incubation, the media were removed and cells were immediately lysed and centrifuged. DCF fluorescence of the cell lysates was measured using a microplate reader with excitation and emission wavelengths of 488 and $515 \mathrm{~nm}$ respectively.

blocked the HNE-induced suppression of steroidogenesis, further confirming a direct inhibitory action of HNE (Fig. 2). Since steroidogenic tissues are constantly exposed to ROS as byproducts of both oxidative phosphorylation and steroid biosynthetic pathways, we also incubated normal Y1-BS1 cells with these two antioxidants to determine whether such manipulations would also impact steroidogenesis in a positive manner. Upon incubation of Y1-BS1 cells with MnTMPyP or NAC, steroid synthesis in response to either $\mathrm{Bt}_{2} \mathrm{cAMP}$ alone or in the presence of $\mathrm{HDL}_{3}$ was significantly upregulated indicating inhibition of steroidogenesis by the endogenously produced ROS (Table 2). Overall, these results

Table 2 Effect of reactive oxygen species (ROS) scavengers on steroid hormone synthesis and secretion by the mouse Y1-BS1 mouse adrenocortical cells. Results are mean \pm s.E.M. of four independent experiments. Y1-BS1 mouse adrenocortical tumor cells were incubated in a serum-free medium $\pm \mathrm{hHDL}_{3}(500 \mu \mathrm{g}$ protein $/ \mathrm{ml}), \pm \mathrm{Bt}_{2} \mathrm{CAMP}(2.5 \mathrm{mM}), \pm \mathrm{MnTMPyP}(10 \mu \mathrm{M})$, or \pm NAC $(20 \mathrm{mM})$ at $37^{\circ} \mathrm{C}$ for $5 \mathrm{~h}$. Following incubation, medium was collected separately from each dish and stored frozen until analyzed. Steroids were extracted from the medium using methylene chloride and quantified by fluorescence in $65 \%$ sulfuric acid-35\% ethanol using $20 \alpha$-dihydroprogesterone as a standard. The cell lysates were analyzed for protein content

20 $\alpha$-dihydroprogesterone (ng/mg cell protein $/ 5 \mathrm{~h} \pm$ s.E.M.)

\begin{tabular}{|c|c|c|c|}
\hline & Control & $\begin{array}{l}\text { MnTMPyP } \\
(10 \mathrm{mM})\end{array}$ & $\begin{array}{l}\text { NAC } \\
(20 \mathrm{mM})\end{array}$ \\
\hline \multicolumn{4}{|l|}{ Additions } \\
\hline None & $27 \cdot 5 \pm 4 \cdot 8$ & $26 \cdot 0 \pm 6 \cdot 7$ & $23 \cdot 3 \pm 4 \cdot 3$ \\
\hline $\mathrm{hHDL}_{3}(500 \mathrm{mg} / \mathrm{ml})$ & $56 \cdot 3 \pm 5 \cdot 8$ & $66 \cdot 8 \pm 9 \cdot 4$ & $68 \cdot 3 \pm 9 \cdot 3$ \\
\hline $\mathrm{Bt}_{2} \mathrm{CAMP}(2.5 \mathrm{mM})$ & $694 \pm 51$ & $1023 \pm 105^{*}$ & $1094 \pm 121^{+}$ \\
\hline $\mathrm{Bt}_{2} \mathrm{CAMP}+\mathrm{hHDL}_{3}$ & $1673 \pm 154$ & $2663 \pm 310^{\ddagger}$ & $2463 \pm 276^{\S}$ \\
\hline
\end{tabular}

${ }^{*} P=0 \cdot 0306 ;{ }^{\dagger} P=0 \cdot 0229 ;{ }^{\ddagger} P=0 \cdot 0416 ;{ }^{\circledR} P=0 \cdot 0467$. 
suggest that steroidogenic pathway is highly sensitive to and negatively impacted by ROS possibly through enhanced lipid peroxidation and oxidative damage to membranes crucial for cholesterol to mitochondria or other events connected with the steroidogenesis.

Effects of superoxide- and HNE-induced oxidative stress on the activation state of MAPKs

Enhanced oxidative stress is known to activate multiple MAPK signaling cascades in many cellular systems (Finkel \& Holbrook 2000, Martindale \& Holbrook 2002, Matsuzawa \& Ichijo 2005, McCubrey et al. 2006). To identify the MAPK signaling pathways activated in Y1-BS1 cells in response to superoxide, $\mathrm{H}_{2} \mathrm{O}_{2}$, and HNE, we assessed the activation of ERK1/2, JNK1/ 2 , and p38 MAPK using western blot analysis with antibodies that recognize either the phosphorylated or total content of each of the three MAPKs. Figure 4 shows total and phosphorylated forms of MAPKs assayed in cell extracts from Y1-BS1 cells pretreated with or without oxidants (X/XO or HNE). In control (vehicle-treated) cells, significant expression of the phosphorylated form of ERK1/2 and p38 MAPK was detected but very little ofJNK1 (JNK-46) and JNK2 (JNL-54). The XO/ $\mathrm{X}$-generated superoxide treatment led to a marked increase in

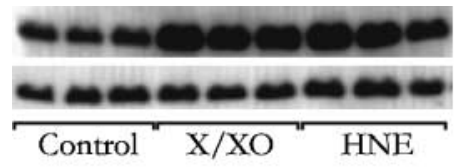

\section{Phospho p38 MAPK Total p38 MAPK}
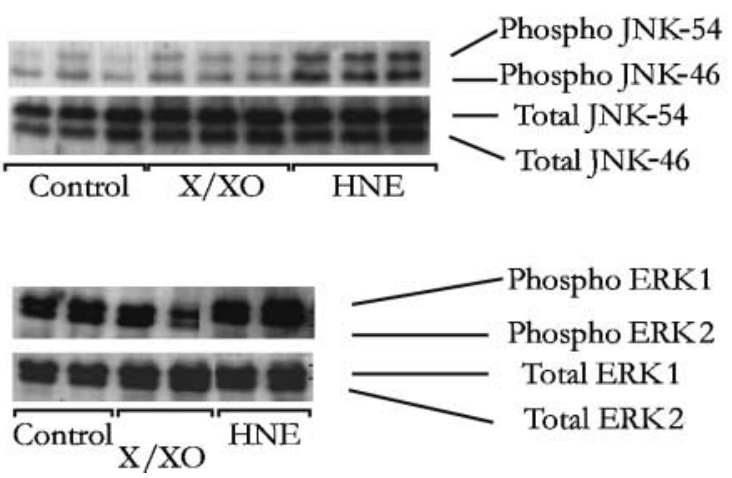

Figure 4 Phosphorylation of ERK1/2, JNK1/2 and p38 MAPK by oxidants in cultured Y1-BS1 cells. Triplicate dishes of cultured Y1BS1 adrenal cells were incubated with xanthine $(0.25 \mathrm{mM})+$ xanthine oxidase $(20 \mathrm{mU} / \mathrm{ml})$ (to generate superoxide in situ), or HNE $(50 \mu \mathrm{M})$ for $1 \mathrm{~h}$. Equal aliquots of solubilized samples (30-40 $\mu$ g protein) were subjected to SDS-PAGE and immunoblotted with antibodies against ERK1/2 phosphorylated at $\mathrm{Thr}^{202} / \mathrm{Tyr}^{204}(\mathrm{P}-$ ERK1/2), against p38 MAPK phosphorylated at $\mathrm{Thr}^{180} / \mathrm{Tyr}^{182}(\mathrm{P}-\mathrm{p} 38$ MAPK), or JNK1/2 phosphorylated at $\mathrm{Thr}^{183} / \mathrm{Tyr}^{185}$ (P-JNK1/2). The blots were stripped and re-probed using the antibodies that recognize total (phospho- plus non-phospho forms) ERK1/2, p38 $\alpha$ MAPK, and JNK $1 / 2$ proteins. The blots shown represent three independent experiments. Numerical results were obtained by densitometric scanning of the individual blots. the amount of the phosphorylated form of 38 MAPK, but not of phosphorylated ERK1/2 and JNK1/2. Superoxide and HNE also increased the levels of phospho-p38 MAPK. Although, HNE treatment somewhat enhanced the phosphorylation of ERK1/2 and JNK1 (JNK-46) and JNK2 (JNK-54), the degree of their phosphorylation was several fold lower than that seen with p38 MAPK. Interestingly, the total amount (protein level) of p38 MAPK remained constant following treatment of cells with superoxide, or HNE for up to $1 \mathrm{~h}$ (Fig. 4), suggesting that oxidant effects on p38 MAPK are due to changes in the phosphorylation (activation) status of this kinase.

Kinetic dose-response studies were carried out to further establish the stimulatory actions of these three oxidants on $\mathrm{p} 38$ MAPK phosphorylation and the results are presented in Fig. 5A-C. The activation of $\mathrm{p} 38 \mathrm{MAPK}$ by $\mathrm{XO} / \mathrm{X}$ generated superoxide was rapid $(10 \mathrm{~min})$ and sustained (Fig. 5A). Dose-response studies demonstrated that $\mathrm{H}_{2} \mathrm{O}_{2}$ significantly increased the phosphorylation of p38 MAPK (approximately fivefold) at $0.1 \mathrm{mM}$ reaching a maximum around $0.25 \mathrm{mM}$ (Fig. 5C). Likewise, the stimulatory action of HNE also showed concentration dependence with a maximal effect observed around $50 \mu \mathrm{M}$ (Fig. 5B).

Involvement of p38 MAPK during oxidant-mediated inhibition of steroidogenesis

Data shown in Figs 4 and 5 suggest possible involvement of the p38 MAPK signaling cascade in oxidant-induced loss of

\section{A $\mathrm{X} / \mathrm{XO}$}

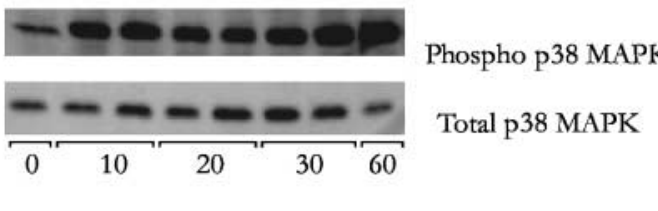

(min)

B HNE

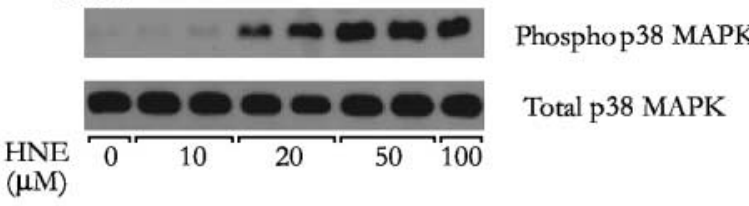

\section{C $\mathrm{H}_{2} \mathrm{O}_{2}$}

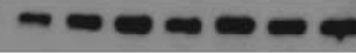

Phospho p38 MAPK

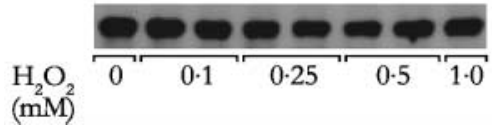

Total p38 MAPK

Figure 5 Kinetics and dose-response effects of superoxide, $\mathrm{H}_{2} \mathrm{O}_{2}$, and HNE on p38 MAPK activation. Y1-BS1 adrenal cells were treated with $(\mathrm{A})$ xanthine $(0 \cdot 25 \mathrm{mM})+$ xanthine oxidase $(20 \mathrm{mU} / \mathrm{ml})$ for varying incubation time $(10,20,30$ or $60 \mathrm{~min})$, (B) $0,10,20,50$, or $100 \mu \mathrm{M} \mathrm{HNE}$ for $1 \mathrm{~h}$ and (C) $0,0 \cdot 1,0 \cdot 25,0 \cdot 5$, or $1 \mathrm{mM} \mathrm{H}_{2} \mathrm{O}_{2}$ for $1 \mathrm{~h}$. The cell lysates were analyzed by immunoblotting with antibodies against phosphorylated or total p38 MAPK (Fig. 4). Data shown are representative of two independent experiments. 
adrenal steroid hormone production. We next investigated the potential relationship between oxidative stress-induced activation of $\mathrm{p} 38$ MAPK and the ability of excessive oxidative stress to inhibit hormone-stimulated and lipoprotein-supported steroid synthesis. One way to determine the involvement of p38 MAPK in mediating the inhibitory actions of oxidative stress on adrenal steroidogenesis is to examine the effects of two specific and cell-permeable chemical inhibitors of p38 MAPK, SB203580, and SB202190 (Lee et al. 1994, Cueda et al. 1995). Treatment of Y1-BS1 adrenal cells with a maximal effective dose of SB203580 $(10 \mu \mathrm{M})$ potentiated the stimulatory action effects of $\mathrm{Bt}_{2} \mathrm{cAMP}$ and $\mathrm{Bt}_{2} \mathrm{cAMP}+\mathrm{hHDL}_{3}$ (Fig. 6). The effect of SB202190 $(10 \mu \mathrm{M})$, a more potent inhibitor of p38 MAPK, was also examined in the face of $\mathrm{Bt}_{2} \mathrm{cAMP}$ or $\mathrm{Bt}_{2} \mathrm{CAMP}+$ $\mathrm{hHDL}_{3}$-stimulated steroid production. In agreement with the effect of SB203580, SB202190 also increased the steroid production over that observed with $\mathrm{Bt}_{2} \mathrm{CAMP}$ alone or $\mathrm{Bt}_{2} \mathrm{cAMP}+\mathrm{hHDL}_{3}$ (Fig. 6). By contrast, SB202474, the biologically inactive inhibitor of p38 MAPK had no effect on steroidogenesis. To determine the potential involvement of ERK1/2 and JNK1/2 in the regulation of adrenal steroidogenesis, two MEK 1/2 inhibitors PD98059 (Alessi et al. 1995) and U0126 (Favata et al. 1998), and SP600125 a JNK1/2 inhibitor (Bennett et al. 2001) were utilized. (MEK1/2 are upstream kinases that activate ERKs). Treatments with either PD98059 $(30 \mu \mathrm{M})$, U0126 $(10 \mu \mathrm{M})$, inactive analog U0124 $(10 \mu \mathrm{M})$, or SP600125 were ineffective in upregulating $\mathrm{Bt}_{2} \mathrm{cAMP}$ or $\mathrm{Bt}_{2} \mathrm{cAMP}$ plus lipoprotein-stimulated steroid production (Fig. 6). None of the various inhibitors had any significant effect on the overall viability of the treated cells.

As shown above, treatment of Y1-BS1 cells with oxidants leads to increased stimulation of p38 MAPK activity, but at the same time inhibits hormone- and/or lipoproteinsupported steroid production (Figs 4 and 5). To investigate whether inhibition of the p38 MAPK cascade contributed to the protective effect conferred by ROS scavengers and p38 MAPK inhibitors in response to oxidant treatment, the levels of phospho-p38 MAPK were examined by western blot analysis. As described above, the level of phospho-p38 MAPK was enhanced in cell extracts prepared from superoxide (X/XO)- or HNE-treated Y1-BS1 cells. However, pretreatment with MnTMPyP and NAC completely suppressed the superoxide- and HNE-induced increase in the levels of phosphorylation of p38 MAPK respectively (data not shown). Likewise, use of $\mathrm{p} 38$ MAPK inhibitors completely prevented the superoxide- or HNE-induced enhanced phosphorylation of p38 MAPK. We, therefore, investigated the effect of p38 MAPK inhibition on superoxide- and HNE-inhibited steroidogenesis. In agreement with previous results, treatment with $\mathrm{X} / \mathrm{XO}$ or HNE alone caused a significant reduction in $\mathrm{Bt}_{2} \mathrm{cAMP}+\mathrm{hHDL}_{3}$-stimulated $20 \alpha$-dihydroprogesterone production (Fig. 7). Treatment of cells with either X/XO or HNE in the presence of SB203580 or SB202190 not only attenuated but restored steroidogenic function to almost control level (Fig. 7). Under identical experimental
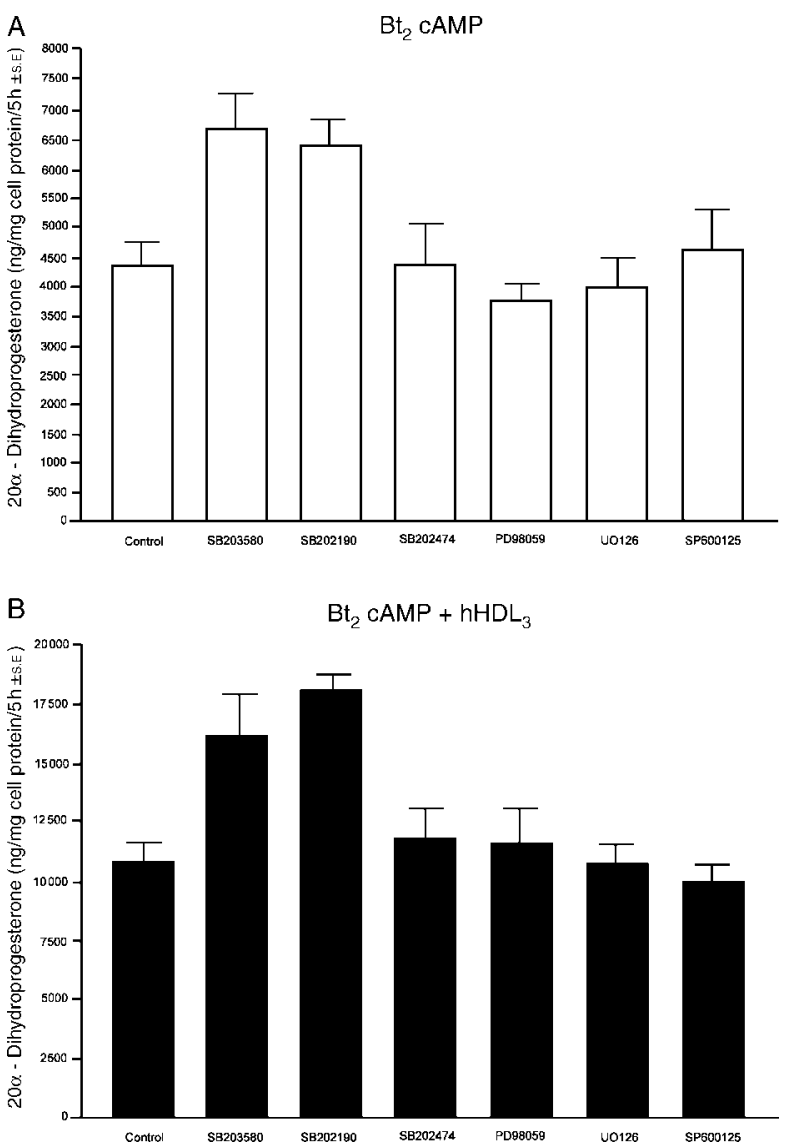

Figure 6 Effect of MAPK signaling pathway inhibitors on (A) $\mathrm{Bt}_{2} \mathrm{CAMP}$ and (B) Bt2cAMP $+\mathrm{hHDL}_{3}$-stimulated $20 \alpha$-dihydroprogesterone production. $\mathrm{Y} 1-\mathrm{BS} 1$ cells were incubated for $5 \mathrm{~h}$ in culture medium supplemented with $\mathrm{Bt}_{2} \mathrm{CAMP}(2 \cdot 5 \mathrm{mM})$ or $\mathrm{Bt}_{2} \mathrm{CAMP}+\mathrm{hHDL}_{3}$ $(500 \mu \mathrm{g} / \mathrm{ml}) \pm \mathrm{SB} 203580(10 \mu \mathrm{M}), \mathrm{SB} 202190(10 \mu \mathrm{M}), \mathrm{SB} 202474$ $(10 \mu \mathrm{M})$, PD98059 $(30 \mu \mathrm{M}), \mathrm{U} 0126(10 \mu \mathrm{M})$ or SP600125 $(10 \mu \mathrm{M})$. At the end of incubation, medium samples were quantified for the production of $20 \alpha$-dihydroprogesterone. In some cases, cell viability was determined using a sensitive MTT assay as described under the experimental section. The results are mean \pm S.E.M. of four independent experiments. The amount of $20 \alpha$-dihydroprogesterone produced under basal condition was $26.5 \pm 3.7 \mathrm{ng} / \mathrm{mg}$ cell protein $/ 5 \mathrm{~h}$. $P<0 \cdot 005, \mathrm{Bt}_{2} \mathrm{CAMP}$ vs Bt ${ }_{2} \mathrm{CAMP}+\mathrm{SB} 203580 ; P<0 \cdot 02, \mathrm{Bt}_{2-}$ $\mathrm{CAMP}+\mathrm{hHDL}_{3}$ versus $\mathrm{Bt}_{2} \mathrm{CAMP}+\mathrm{hHDL}_{3}+\mathrm{SB} 203580 ; P<0 \cdot 02$, $\mathrm{Bt}_{2} \mathrm{CAMP}$ versus $\mathrm{Bt}_{2} \mathrm{CAMP}+\mathrm{SB} 202190 ; P<0 \cdot 01, \mathrm{Bt}_{2} \mathrm{CAMP}+\mathrm{hHDL}_{3}$ versus $\mathrm{Bt}_{2} \mathrm{CAMP}+\mathrm{hHDL}+\mathrm{SB} 202190$.

conditions, both compounds also prevented oxidant-stimulated increases in $\mathrm{p} 38$ MAPK as indicated by inhibition of $\mathrm{p} 38$ MAPK-catalyzed threonine phosphorylation of ATF2 (data not shown).

Since SB203580 and SB202190 inhibit only p38 MAPK $\alpha / \beta$ isoforms, it raised the possibility that antisteroidogenic actions of excessive oxidative stress is primarily mediated by either $\mathrm{p} 38$ MAPK $\alpha, \mathrm{p} 38$ MAPK $\beta$ or both. To address this issue, $\mathrm{qPCR}$ was used to assess endogenous mRNA levels of p38 MAPK $\alpha$, p38 MAPK $\beta$, p38 MAPK $\gamma$ and $\mathrm{p} 38$ MAPK $\delta$ isoforms. The results presented in Fig. 8 indicate that Y1-BS1 cells predominantly 

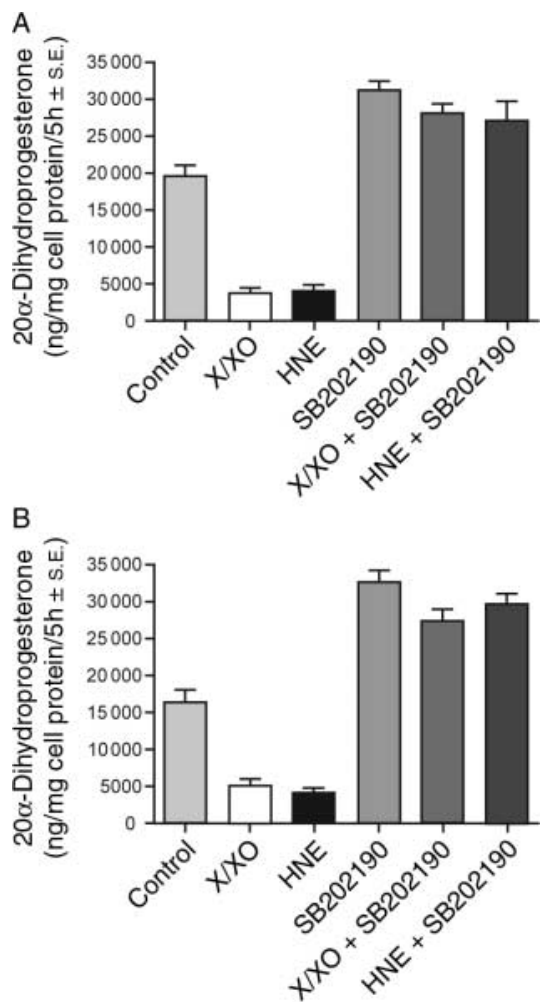

Figure 7 Effect of p38 MAPK inhibitors on superoxide or HNE inhibited steroid production. Results are mean \pm s.E.M. of three independent experiments. Y1-BS1 cells cultured in $60 \mathrm{~mm}$ dishes were treated with xanthine $(0.25 \mathrm{mM})+$ xanthine oxidase $\left(20 \mathrm{mU} / \mathrm{ml}\right.$ ) (to generate a flux of superoxide anion, $\mathrm{O}_{2}^{-}$) or $\mathrm{HNE}$ $(50 \mu \mathrm{M}) \pm$ SB203580 or SB202190 $(10 \mu \mathrm{M})$ for $1 \mathrm{~h}$. Following treatment, dishes were rapidly washed and incubated with $\mathrm{Bt}_{2}$ CAMP $(2.5 \mathrm{mM}) \pm \mathrm{hHDL}_{3}(500 \mu \mathrm{g} / \mathrm{ml}) \pm$ respective SB203580 or SB202190 $(10 \mu \mathrm{M})$ for $5 \mathrm{~h}$. Following incubation, the incubation media was collected and stored frozen until analyzed. Steroids were extracted from the medium using methylene chloride and quantified by fluorescence in $65 \%$ sulfuric acid-35\% ethanol using $20 \alpha$-dihydroprogesterone as a standard. The amount of $20 \alpha-$ dihydroprogesterone produced under basal condition was $22 \cdot 9 \pm$ $4.0 \mathrm{ng} / \mathrm{mg}$ cell protein $/ 5 \mathrm{~h}$. (A) $P<0 \cdot 002$, Control versus $X / X O$; $P<0 \cdot 00$, control versus $\mathrm{HNE} ; P<0 \cdot 007$, control vs SB203580; $P<0 \cdot 01$, control versus $\mathrm{X} / \mathrm{XO}+\mathrm{SB} 203580 ; P<0 \cdot 01$, control vs $\mathrm{HNE}+\mathrm{SB} 203580$. (B) $P<0 \cdot 0005$, Control versus $\mathrm{X} / \mathrm{XO} ; P<0 \cdot 0008$, control vs HNE; $P<0 \cdot 003$, control vs SB202190; $P<0 \cdot 01$, control versus $\mathrm{X} / \mathrm{XO}+\mathrm{SB} 202190 ; P<0 \cdot 03$, control versus $\mathrm{HNE}+$ SB202190.

express p38 MAPK $\alpha$ isoform along with only low levels of p38 MAPK $\gamma$. By contrast, little or no expression of p38 MAPK $\beta$ and p38 MAPK $\delta$ isoforms was noted. These results, thus, strongly support the possibility that p38 MAPK $\alpha$ is the predominant, if not the sole mediator of oxidative stress inhibition of steroid synthesis.

To further substantiate the above findings, we also employed various dominant-negative mutant forms of p38 MAPKs and consecutively active and dominant-negative MKK3/MKK6 constructs to genetically alter the function of p38 MAPK. MKK3 and MKK6 are upstream kinases that

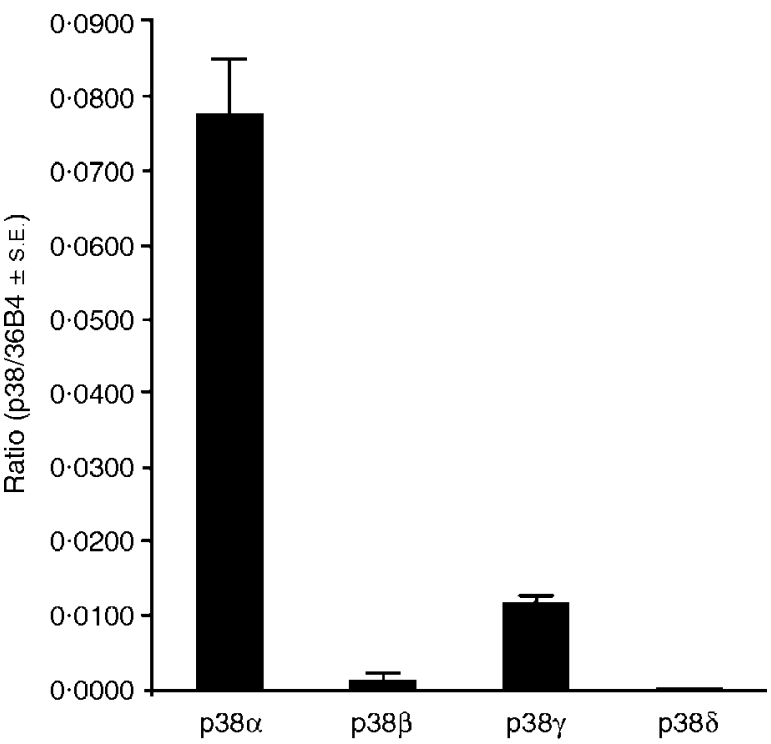

Figure 8 p38 MAPK $\alpha$, p38 MAPK $\beta$, p38MAPK $\gamma$ and p38 MAPK $\delta$ mRNA levels in cultured Y1-BS1 cells. Total cellular RNA was extracted, cDNA synthesized, and aliquots of cDNA were used as template reactions containing either primers for $\mathrm{p} 38 \mathrm{MAPK} \alpha$, p38 MAPK $\beta$, p38MAPK $\gamma$, p38 MAPK $\delta$ or $36 B 4$. Real-time PCR was performed with an ABI Prism 7900 System using SYBR Green master mix reagent and specific primers as listed in Table 1. Data are presented as ratio of p38 MAPK genes normalized to 36B4. Results are mean \pm s.E.M. of three independent experiments performed in triplicates.

phosphorylate and activate p38 MAPK isoforms (Jiang et al. 1997, Enslen et al. 1998). Initially, Y1-BS1 cells were transiently transfected with FLAG- or c-myc-tagged dominant-negative(dn) dnMKK3, dnMKK6, dnMKK7, and dnMKK7, constitutively active (ca) caMKK3, caMKK6, or caMKK7 constructs and were subsequently evaluated for their steroidogenic potential. As a negative control, cells were transfected with an empty vector (pcDNA3.1). The immunoblot analysis of cell lysates prepared from transfected cells confirmed a robust expression of the respective MKK proteins (data not shown). Moreover, transfection of Y1-BS1 cells with a dn-MKK3 (Ala) plasmid construct increased steroid production by $\sim 50 \%$ (Table 3 ). Expression of dnMKK6(K82A) also enhanced steroid synthesis in the range of $50-60 \%$. Conversely, introduction of either caMKK3 (Glu) or caMkk6(Glu) constructs reduced the $20 \alpha$-dihydroprogesterone production to approximately half as compared with vector control (Table 3). By contrast, expression of either a constitutively active (caMKK7(73E)) or a dominant-negative form of MKK7 (dnMKK7(73A) or dnMKK7(7K149M)), an upstream activator of JNKs (Tournier et al. 1999), had no effect on the levels of steroid produced (Table 3). These results clearly establish that p38 MAPK acts as a negative modulator of steroidogenesis.

We next sought to define the contribution of individual p38 MAPK isoforms that may mediate the inhibition of steroidogenesis. Presently, there are four known isoforms of 
Table 3 Overexpression of dominant-negative MKK3 and MKK6 upregulate while constitutively active MKK3 and MKK6 suppress steroidogenic response in Y1-BS1 mouse adrenocortical tumor cells. Results are expressed as mean \pm S.E.M. of four independent experiments. Y1-BS1 cells were transiently transfected with an empty vector (control) or expression vectors for dnMKK3(Ala), caMKK3(Glu), dnMKK6(K82A), caMKK6(Glu), dnMKK7(73A), or caMKK7(73E) for $48 \mathrm{~h}$. Bt ${ }_{2} \mathrm{CAMP}(2 \cdot 5 \mathrm{mM})+\mathrm{hHDL}_{3}(500 \mu \mathrm{g}$ protein $/ \mathrm{ml}$ ) were then added, and the incubation continued for another $5 \mathrm{~h}$. At the end of incubation, the medium samples were collected and stored frozen until analyzed for steroid content. Steroids were extracted from the medium using methylene chloride and quantified by fluorescence in $65 \%$ sulfuric acid-35\% ethanol using $20 \alpha$-dihydroprogesterone as a standard. The cells were lysed and cell lysates were used for protein determination and immunoblotting to detect the expression of myc- or FLAG-tagged proteins

\begin{tabular}{|c|c|}
\hline $\begin{array}{l}\text { 20 } \alpha \text {-dihydroprogesterone } \\
\text { (ng/mg cell protein/ } \\
5 \text { h } \pm \text { S.E.M.) }\end{array}$ & $\boldsymbol{P}$ \\
\hline $8327 \pm 1167$ & \\
\hline $12210 \pm 657$ & $0 \cdot 0275$ \\
\hline $4889 \pm 723$ & $0 \cdot 0463$ \\
\hline $13760 \pm 1167$ & $0 \cdot 0148$ \\
\hline $4095 \pm 502$ & $0 \cdot 0158$ \\
\hline $9112 \pm 1138$ & NS \\
\hline $8891 \pm 1037$ & NS \\
\hline $8022 \pm 1285$ & NS \\
\hline
\end{tabular}

ca, catalytically active; dn, dominant negative.

p38 MAPK identified as p38 MAPK $\alpha$, p38 MAPK $\beta$, p38

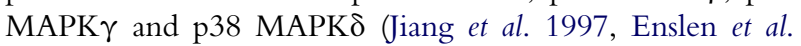
1998). To test their relative actions on steroidogenesis, we transfected Y1-BS1 cells with the dominant-negative (AF) constructs of each of these isoforms and subsequently measured steroid production. The dnp38 MAPK $\alpha$ (AF) and dnp38 MAPK $\beta$ (AF) significantly increased steroidogenic function compared to vector transfected cells (Table 4). The other two dominant-negative mutants, dnp38 MAPK $\gamma$ (AF) and dnp38 MAPK $\delta$ (AF) also slightly, but reproducibly, increased steroid production, although the data did not achieve statistical significance. From these detailed studies, we conclude that excessive oxidative stress-induced inhibition of steroidogenesis requires the activation of and is mediated by p38 MAPK.

\section{Discussion}

Recently we have shown that p38 MAPK is specifically activated in intact rat adrenals during aging and that this activation is linked to age-induced excessive oxidative stress and subsequent loss of steroidogenic response (Abidi et al. 2008). This study provides further evidence that oxidantinduced inhibition of adrenal steroidogenesis requires participation of p38 MAPK and that pharmacological and genetic inhibition of p38 MAPK activity prevents the
Table 4 Overexpression of dominant-negative p38 mitogen-activated protein kinase (MAPK) $\alpha$ and p38 MAPK $\beta$ upregulate steroidogenic response in Y1-BS1 mouse adrenocortical tumor cells. Results are expressed as mean \pm S.E.M. of four independent experiments. Y1-BS1 cells were transiently transfected with an empty vector (control) or expression vectors for dnp38 MAPK $\alpha$, dnp38 MAPK $\beta$, dnp38 MAPK $\gamma$, or dnp38 MAPK $\delta$ for 48 h. Bt ${ }_{2}$ CAMP $(2.5 \mathrm{mM})+\mathrm{hHDL}_{3}(500 \mu \mathrm{g}$ protein $/ \mathrm{ml})$ were then added and the incubation continued for another $5 \mathrm{~h}$. At the end of incubation, the medium samples were collected and stored frozen until analyzed for steroid content. Steroids were extracted from the medium using methylene chloride and quantified by fluorescence in $65 \%$ sulfuric acid- $35 \%$ ethanol using $20 \alpha$-dihydroprogesterone as a standard. The cells were lysed and cell lysates used for protein determination and immunoblotting of FLAG-tagged p38 MAPK proteins

\begin{tabular}{ll}
$\begin{array}{l}\text { 20 } \boldsymbol{\alpha} \text {-dihydroprogesterone } \\
\text { (ng/mg cell protein/ } \\
5 \text { h } \pm \text { S.E.M.) }\end{array}$ & \\
\hline & \\
$9775 \pm 883$ & \\
& \\
$14580 \pm 1276$ & $0 \cdot 0212$ \\
$15380 \pm 1709$ & $0 \cdot 0268$ \\
$11810 \pm 812$ & NS \\
$11470 \pm 1598$ & NS \\
\end{tabular}

\section{Expression constructs Control (vector DNA alone) dnp38 MAPK $\alpha(A F)$ dnp38 MAPK $\beta$ (AF) dnp38 MAPK $\gamma(\mathrm{AF})$ dnp38 MAPKס (AF)}

dn, dominant negative.

oxidant-induced loss of steroid hormone production. This is the first demonstration of involvement of p38 MAPK in the negative regulation of steroidogenesis.

Initially our efforts were directed at determining the functional consequences of a potential interaction between oxidative stress and p38 MAPK using oxidant-treated mouse adrenocortical Y1-BS1 cells as an in vitro cell model system. Three different oxidants, namely superoxide, $\mathrm{H}_{2} \mathrm{O}_{2}$, and HNE were selected on the basis that superoxide anion and $\mathrm{H}_{2} \mathrm{O}_{2}$ are the main oxidants generated as a byproduct of the oxidative phosphorylation and other cellular oxidative pathways (Azhar et al. 1995, Finkel \& Holbrook 2000), while aldehydic product HNE is produced during lipid peroxidation of membrane polyunsaturated fatty acids (Esterbauer et al. 1991). Our results indicate that treatment of cells with any of the three types of oxidants caused a similar but significant reduction in steroidogenesis. Moreover, inhibitory effects of both superoxide anion and $\mathrm{H}_{2} \mathrm{O}_{2}$ were completely attenuated when cell incubations were conducted in the presence of MnTMPyP, a cell-permeable SOD/catalase mimetic (Pimental et al. 2001). Likewise, blockade of the HNE effect was observed when the cells were simultaneously exposed to the antioxidant NAC. These results suggest that superoxide anion, $\mathrm{H}_{2} \mathrm{O}_{2}$, and $\mathrm{HNE}$ specifically inhibit steroid hormone production and that such oxidants are likely to be involved in the molecular mechanisms underlying the agerelated decline in adrenal steroidogenesis. Furthermore, the fact that all three oxidants were equally effective in inhibiting steroid synthesis implies that they either act in concert or in a sequential manner to interfere with the steroidogenic process. 
While relatively less reactive, $\mathrm{O}_{2}^{--}$and $\mathrm{H}_{2} \mathrm{O}_{2}$ can individually cause oxidative damage under certain conditions. However, they elicit more damaging effects when present together or in combination with other reactive species (Girotti 1998). The most likely possibility is the iron-mediated reduction of $\mathrm{H}_{2} \mathrm{O}_{2}$ by $\mathrm{O}_{2}^{--}$by a Haber-Weiss reaction $\left[\mathrm{O}_{2}^{--}+\mathrm{Fe}^{2+} \rightarrow\right.$ $\left[\mathrm{O}_{2}^{--}+\mathrm{Fe}^{2+} \rightarrow \mathrm{O}_{2}+\mathrm{Fe}^{2+}\right] \quad$ (a); $\quad 2 \mathrm{O}_{2}^{--}+2 \mathrm{H}^{+} \rightarrow \mathrm{O}_{2}+$ $2 \mathrm{O}_{2}^{--}+2 \mathrm{H}^{+} \rightarrow \mathrm{O}_{2}+\mathrm{H}_{2} \mathrm{O}_{2}$ (b); $\mathrm{H}_{2} \mathrm{O}_{2}+\mathrm{Fe}^{2+} \rightarrow \mathrm{Fe}^{3+}+$ $\left.\mathrm{H}_{2} \mathrm{O}_{2}+\mathrm{Fe}^{2+} \rightarrow \mathrm{Fe}^{3+}+\mathrm{OH}^{-}+{ }^{\circ} \mathrm{OH}(\mathrm{c})\right]$, leading to formation of hydroxyl radical $(\cdot \mathbf{O H})$, a highly reactive and strong oxidant (Kehrer 2000, Welch et al. 2002). Indeed, ${ }^{\circ} \mathrm{OH}$ is the well-accepted initiator of membrane lipid peroxidation and is responsible for the generation of lipid oxidation products including HNE. In this scenario, we believe that the combined actions of $\mathrm{H}_{2} \mathrm{O}_{2}$ and $\mathrm{O}_{2}^{--}$may facilitate the enhanced production of ${ }^{\circ} \mathrm{OH}$, thereby potentially increasing the extent of peroxidative damage of membrane lipids leading to the increased formation of HNE and consequently, inhibition of steroidogenesis.

Treatment of mouse adrenal Y1-BS1 cells with either $\mathrm{O}_{2}^{--}$, $\mathrm{H}_{2} \mathrm{O}_{2}$, or HNE also activated p38 MAPK in a time- and concentration-dependent manner. These results are in agreement with recent data from our laboratory showing increased stimulation of adrenal p38 MAPK in response to excessive oxidative stress that occurs during aging (Abidi et al. 2008). To elucidate the role of the p38 MAPK signaling cascade in oxidantinduced inhibition of steroid synthesis, we made use of both cellpermeable chemical inhibitors of $\mathrm{p} 38$ MAPK as well as genetic approaches involving either mutant cDNA constructs of $\mathrm{p} 38$ MAPKs or their upstream activators MKK3 and MKK6. Treatment of Y1-BS1 cells with specific inhibitors of p38 MAPK, SB203580, and SB202190 completely prevented oxidant-dependent inhibition of steroid production. Likewise, both inhibitors completely prevented oxidant-mediated increases in p38 MAPK activity as indicated by inhibition of ATF2 phosphorylation (a p38 MAPK substrate). By contrast, SB202474, a control compound that does not inhibit p38 MAPK activity had no effect on oxidant-mediated inhibition of steroidogenic response (Lee et al. 1994). Interestingly, the ability of two 338 MAPK inhibitors to enhance steroid production in untreated control cells further suggests that p 38 MAPK functions as a negative modulator of adrenal steroidogenesis even under normal physiological conditions. To establish the specificity of p38 MAPK inhibitors, we also investigated the effects of PD98059 and U0126, structurally unrelated, specific inhibitors of the ERK activators, MEK1 and MEK2. Treatment of cells with either of the two inhibitors did not prevent oxidantinduced loss of steroidogenic function. Likewise, a specific JNK inhibitor, SP600125, had no significant effect on steroid synthesis following treatment of cells with either $\mathrm{H}_{2} \mathrm{O}_{2}^{--}$or HNE.

The specificity of SB203580 and SB202190 noted above indicates that prevention of the oxidant-mediated inhibition of steroidogenesis resulted from the blockade of p38 MAPK activity. To further elucidate whether the p38 MAPK signaling cascades functions as a negative regulator of and directly interferes with adrenal steroidogenic function, we directly examined the effects of various dominant-negative ( $\mathrm{dn})$ and constitutively active (ca) constructs of MKK3, MKK6, and p38 MAPK isoforms; MKK3 and MKK6 kinases are specific upstream activators of p38 MAPKs (Jiang et al. 1997, Enslen et al. 1998). Transient expression of a dominant-negative form of either MKK3(Ala) or MKK6(K82A) significantly increased the steroidogenic response, whereas expression of constitutively active forms of MKK3(Glu) and MKK6(Glu) reduced the steroidogenic response by $\sim 50 \%$. A similar inhibitory effect was observed with the use of dominant-negative mutants of $p 38$ MAPK isoforms (referred to here as dnp38 MAPK $\alpha$ (AF), dnp38 MAPK $\beta$ (AF), dnp38 MAPK $\gamma$ (AF), and dnp38 MAPK $\delta(\mathrm{AF})$ ), although we noticed subtle differences in the relative contributions of the four isoforms. For instance, treatment with dnp38 MAPK $\alpha$ (AF) and dnp38 MAPK $\beta$ $(\mathrm{AF})$ increased stimulation of steroid production. On the other hand, although the use of dnp38 MAPK $\gamma$ (AF) and dnp38 MAPK $\delta(\mathrm{AF})$ also enhanced steroidogenesis, the results were not statistically significant. The qPCR measurements further indicated that Y1-BS1 adrenal cells express extremely high levels of p38 MAPK $\alpha$ mRNA; approximately eightfold higher than second most expressed p38 MAPK $\gamma$ mRNA. For p38 mAPK $\beta$ and $\mathrm{p} 38 \mathrm{MAPK} \delta$, there was little or no mRNA expression. Taken together, these various observations suggest that activation of p38 MAPK by oxidative stress is a necessary event in the oxidant-mediated inhibition of steroid production. This is the first report implicating p38 MAPK signaling cascade as a negative modulator of adrenal steroidogenesis.

The exact role played by p38 MAPK in oxidative stressdependent inhibition of steroidogenesis remains unclear at the present time. However, because multiple kinases and transcription factors have been identified as p38 MAPK substrates, this suggests that any of these processes could potentially contribute to the negative actions of $\mathrm{p} 38$ MAPK on steroidogenesis (Lewis et al. 1998, Widmann et al. 1999, Kyriakis \& Avruch 2001, Raman et al. 2007, Whitmarsh 2007). One line of investigation supports a role for $\mathrm{p} 38$ MAPK in positively modulating cyclooxygenase-2 (COX-2), which is known to negatively impact steroid hormone synthesis (Nakamura \& Sakamoto 2001, Wang et al. 2003, Frungieri et al. 2006). Several studies have demonstrated that expression of COX-2 is positively regulated by oxidants such as superoxide anion, $\mathrm{H}_{2} \mathrm{O}_{2}$, and HNE (Nakamura \& Sakamoto 2001, Kiritoshi et al. 2003, Kumgai et al. 2004, Yang et al. 2005, 2006). Furthermore, a number of studies have shown that engagement of $\mathrm{p} 38 \mathrm{MAPK}$ is necessary for oxidant-dependent induction of COX-2 (Guan et al. 1998, Lasa et al. 2000, Hendrickx et al. 2003, Zarrouki et al. 2007). When considering the possibility that COX-2 is a well-established negative modulator of steroid biosynthesis (Nakamura \& Sakamoto 2001, Wang et al. 2003, Frungieri et al. 2006), there is a likely possibility that COX-2 may be involved in the p38 MAPK-mediated downregulation of steroidogenesis. Indeed, it has been recently demonstrated that COX-2 downregulates the gene expression of StAR (Wang et al. 2003) (the StAR protein, in concert with several other proteins, especially TSPO facilitate the rate-limiting transfer of 
cholesterol to the mitochondrial inner membrane where the substrate cholesterol is converted to steroid precursor, pregnenolone by CYP11A1 (P450 scc; $_{\text {; }}$ Liu al. 2003, Manna \& Stocco 2005)). Furthermore, our own unpublished preliminary data suggest that p38 MAPK functions as a suppressor of StAR promoter activity in adrenal and Leydig cell lines (S M Zaidi, unpublished observations). Recently, S M Zhao et al. (2006) have provided evidence for stabilization of $3.5 \mathrm{~kb}$ StAR mRNA transcript by arsenite/anisomycin- (non-specific stimulators of p38 MAPK) sensitive putative protein kinase(s) in an SB203580-independent manner. Use of p38 MAPK inhibitor, SB203580 also stabilized the $3.5 \mathrm{~kb}$ StAR mRNA transcript, which was completely blocked by an inhibitor of ERK pathway (MEK innibitor PD98059). Interestingly, arsenite/anisomycinmediated stabilization of $3.5 \mathrm{~kb}$ StAR mRNA transcript occurred in the absence of any detectable increases in StAR phosphorylation. Moreover, incubation of adrenal or Leydig cells with higher arsenite concentrations or longer incubation times resulted in inhibition of StAR expression. Thus, although physiological significance of these disjointed observations and their relevance to StAR function is not apparent, they are in line with our findings that p38 MAPK negatively impacts steroidogenesis.

In conclusion, our data provide direct evidence that activation of the p38 MAPK signaling pathway is functionally linked to the oxidative stress response and mediates its inhibitory effect on adrenal steroid production. This represents a novel cellular mechanism that allows negative modulation of steroidogenesis in response to excessive oxidative insult. Additional studies are underway in this laboratory to further delineate the mechanism by which oxidative stress-mediated activation of p38 MAPK signaling pathway negatively impacts steroidogenesis, particularly impact of oxidants/oxidative stress on the expression of other StARD proteins and potential interactions beween StAR and PBR.

\section{Declaration of Interest}

The authors declare that there is no conflict of interest that would prejudice the impartiality of this scientific work.

\section{Funding}

This work was supported by the Office of Research and Development, Medical Service, Department of Veterans Affairs, and a grant (DK56339) from the National Institutes of Health.

\section{References}

Abidi P, Leers-Sucheta S \& Azhar S 2004 Suppression of steroidogenesis and activator protein-1 transcription factor activity in rat adrenals by vitamin $\mathrm{E}$ deficiency-induced oxidative stress. Journal of Nutritional Biochemistry $\mathbf{1 5}$ 210-219.
Abidi P, Leers-Sucheta S, Cortez Y, Han J \& Azhar S 2008 Evidence that agerelated changes in p38 MAP kinase contribute to the decreased steroid production by the adrenocortical cells from old rats. Aging Cell 7 168-178.

Alessi DR, Cuenda A, Cohen P, Dudley DT \& Saltiel AR 1995 PD 098059 is a specific inhibitor of the activation of mitogen-activated protein kinase kinase in vitro and in vivo. Journal of Biological Chemistry 270 27489-27494. Arlt W 2004 Dehydroepiandrosterone and ageing. Best Practice and Research. Clinical Endocrinology and Metabolism 18 363-380.

Azhar S, Cao L \& Reaven E 1995 Alteration of the adrenal antioxidant system during aging in rats. Journal of Clinical Investigation 96 1414-1424.

Bennett BL, Sasaki DT, Murray BW, O’Leary EC, Sakata ST, Xu W, Leisten JC, Motiwala A, Pierce S, Satoh Y et al. 2001 SP600125, an anthrapyrazolone inhibitor of jun $\mathrm{N}$-terminal kinase. PNAS $\mathbf{9 8}$ 13681-13686.

Bethea CL \& Walker RF 1979 Age-related changes in reproductive hormones and in Leydig cell responsivity in the male Fischer 344 rat. Journal of Gerontology 34 21-27.

Burger HG, Dudley EC, Robertson DM \& Dennerstein L 2002 Hormonal changes in the menopause transition. Recent Progress in Hormone Research $\mathbf{5 7}$ 257-275.

Cao L, Leers-Sucheta S \& Azhar S 2004 Aging alters the functional expression of enzymatic and non-enzymatic anti-oxidant defense system in testicular rat Leydig cells. Journal of Steroid Biochemistry and Molecular Biology 88 61-67.

Chen H, Hardy MP, Huhtaniemi L \& Zirkin BR 1994 Age-related decreased Leydig cell testosterone production in the Brown Norway rat. Journal of Andrology 15 551-557.

Cheng B, Horst IA, Mader SL \& Kowal J 1990 Diminished adrenal steroidogenesis in aging rats: new evidence from adrenal cells cultured from young and aged normal and hypoxic animals. Molecular and Cellular Endocrinology 73 R7-R12.

Chinenov Y \& Kerppola TK 2001 Close encounters of many kinds: Fos-Jun interactions that mediate transcription regulatory specificity. Oncogene $\mathbf{2 0}$ 2438-2452.

Clem BF \& Clark BJ 2006 Association of the mSin3A-histone deacetylase $1 / 2$ corepressor complex with the mouse steroidogenic acute regulatory protein gene. Molecular Endocrinology 20 100-113.

Cueda A, Rouse J, Doza YN, Meier R, Cohen P, Gallagher TF, Young PR \& Lee JC 1995 SB 203580 is a specific inhibitor of a MAP kinase homologue which is stimulated by cellular stresses and interleukin-1. FEBS Letters 364 229-233.

Culty M, Luo L, Yao Z-X, Chen H, Papadopoulos V \& Zirkin BR 2002 Cholesterol transport, peripheral benzodiazepine receptor, and steroidogenesis in aging Leydig cells. Journal of Andrology 23 439-447.

Dalton TP, Shertzer HG \& Puga A 1999 Regulation of gene expression by reactive oxygen. Annual Review of Pharmacology and Toxicology 39 67-101.

Dharia S \& Parker CR 2004 Adrenal androgens and aging. Seminars in Reproductive Medicine 22 361-368.

Edmunds JW \& Mahadevan LC 2004 MAP kinases as structural adaptors and enzymatic activators in transcription complexes. Journal of Cell Science 117 3715-3723.

Englert EP \& Shacter E 2002 Distinct modes of cell death induced by different reactive oxygen species: amino acyl chloramines mediate hypochlorous acid-induced apoptosis. Journal of Biological Chemistry $27720518-20526$.

Enslen H, Raingeaud J \& Davis RJ 1998 Selective activation of p38 mitogenactivated protein (MAP) kinase isoforms by the MAP kinase kinases MKK3 and MKK6. Journal of Biological Chemistry 273 1741-1748.

Esterbauer H, Schauer RJ \& Zollner H 1991 Chemistry and biochemistry of 4-hydroxynonenal, malondialdehyde and related aldehydes. Free Radical Biology and Medicine 11 81-128.

Faust JR, Goldstein JL \& Brown MS 1977 Receptor-mediated uptake of low density lipoprotein and utilization of its cholesterol for steroid biosynthesis in cultured mouse adrenal cells. Journal of Biological Chemistry 252 4861-4871

Favata MF, Horiuchi KY, Manos EJ, Dauleriot AJ, Stradley DA, Feeser WS, Van Dyk DE, Pitts WJ, Earl RA, Hobbs F et al. 1998 Identification of a novel inhibitor of mitogen-activated protein kinase kinase. Journal of Biological Chemistry 273 18623-18632. 
Finkel T \& Holbrook NJ 2000 Oxidants, oxidative stress and the biology of ageing. Nature 408 239-247.

Frungieri MB, Gonzalez-Calvar SI, Parborell F, Albrecht M, Mayerhofer A \& Calandra RS 2006 Cyclooxygenase-2 and prostaglandin F2 in Syrian hamster Leydig cells: inhibitory role on luteinizing hormone/human chronic gonadotropin-stimulated testosterone production. Endocrinology 147 4476-4485.

Giatzakis C, Batarseh A, Dettin L \& Papadopoulos V 2007 The role of Ets transcription factors in the basal transcription of the translocator protein (18 kDa). Biochemistry 46 4763-4774.

Girotti AW 1998 Lipid hydroperoxide generation, turnover, and effector action in biological systems. Journal of Lipid Research 39 1529-1542.

Guan Z, Buckman SY, Miller BW, Springer LD \& Morrison AR 1998 Interleukin-1- $\alpha$ induced cyclooxygenase-2 expression requires activation of both c-Jun NH2-terminal kinase and p38 MAPK signal pathways in rat renal mesangial cells. Journal of Biological Chemistry 273 28670-28676.

Hanukoglu I 2006 Antioxidant protective mechanisms against reactive oxygen species (ROS) generated by mitochondrial P450 systems in steroidogenic cells. Drug Metabolism Reviews 38 171-196.

Harman SM 2005 Testosterone in older men after the Institute of Medicine Report: where do we go from here? Climacteric 8 124-135.

Hendrickx N, Volanti C, Moens U, Seternes OM, de White P, Vandenheede JR, Piette J \& Agostinis P 2003 Up-regulation of cyclooxygenase-2 and apoptosis resistance by 38 MAPK in hypericin-mediated photodynamic therapy of human cancer cells. Journal of Biological Chemistry 278 52231-52239.

Hess J, Angel P \& Schorpp-Kistner M 2004 AP-1 subunits. Journal of Cell Science 117 5965-5973.

Hiroi H, Christenson LK, Chang L, Sammel MD, Berger SL \& Strauss JF III 2004 Temporal and spatial changes in transcription factor binding and histone modifications at the steroidogenic acute regulatory protein (StAR) locus associated with StAR transcription. Molecular Endocrinology 18 791-806.

Holtmann H, Winzen R, Holland P, Eickemeir S, Hoffmann E, Wallach D, Malinin NL, Cooper JA, Resch K \& Kracht M 1999 Induction of interleukin-8 synthesis integrates effects on transcription and mRNA degradation from at least three different cytokine- or stress-activated signal transduction pathways. Molecular and Cellular Biology 19 6742-6753.

Humar M, Loop T, Schmidt R, Hoetzel A, Roesslein M, Andriopoulos N, Pahl HL, Geiger KK \& Pannen BHJ 2007 The mitogen-activated protein kinase p38 regulates activator protein 1 by direct phosphorylation of c-Jun. International Journal of Biochemistry and Cell Biology 39 2278-2288.

Jiang Y, Gram H, Zhao M, New L, Gu J, Feng L, Di Padova F, Ulevitch RJ \& Han J 1997 Characterization of the structure and function of the fourth member of p38 group mitogen-activated protein kinases, p38 . Journal of Biological Chemistry 272 30122-30128.

Jonassen JA, Cooney R, Kennington L, Gravel K, Honeyman T \& Scheid CR 1999 Oxalate-induced changes in the viability and growth of human renal epithelial cells. Journal of the American Society of Nephrology 14 S446-S451.

Kaufman JM \& Vermeulen A 2005 The decline of androgen levels in elderly men and its clinical and therapeutic implications. Endocrine Reviews 26 833-876.

Kehrer JP 2000 The Haber-Weiss reaction and mechanisms of toxicity. Toxicology 149 43-50.

Keller A, Mohamed A, Dröse S, Brandt U, Fleming I \& Brandes RP 2004 Analysis of dichlorodihydrofluorescein and dihydrocalcein as probes for the detection of intracellular reactive oxygen species. Free Radical Research $\mathbf{3 8}$ 1257-1267.

Kelley L, Allan G \& Azhar S 2004 High dietary fructose induces a hepatic stress response resulting in cholesterol and lipid dysregulation. Endocrinology 145 548-555.

Kiritoshi S, Nishikawa T, Sonoda K, Kukidome D, Senokuchi T, Matsuo T, Matsumura T, Tokunaga H, Brownlee M \& Araki E 2003 Reactive oxygen species from mitochondria induce cyclooxygenase- 2 gene expression in human mesangial cells: potential role in diabetic nephropathy. Diabetes $\mathbf{5 2}$ 2570-2577.

Klaunig JE \& Kamendulis LM 2004 The role of oxidative stress in carcinogenesis. Annual Review of Pharmacology and Toxicology 44 239-267.
Kumgai T, Matsukawa N, Kaneko Y, Kusumi Y, Mitsumata M \& Uchida K 2004 A lipid peroxidation-derived inflammatory mediator: identifiaction of 4-hydroxy-2-nonenal as a potential inducer of cyclooxygenase-2 in macrophages. Journal of Biological Chemistry 279 48389-48396.

Kyriakis JM \& Avruch J 2001 Mammalian mitogen-activated protein kinase signal transduction pathways activated by stress and inflammation. Physiological Reviews 81 807-869.

Lasa M, Mahtani KR, Finch A, Brewer G, Saklatvala J \& Clark AR 2000 Regulation of cyclooxygenase $2 \mathrm{mRNA}$ stability by the mitogenactivated protein kinase p38 signaling cascade. Molecular and Cellular Biology 20 4265-4274.

Lee JC, Laydon JT, McDonnell PC, Gallagher TF, Kumar S, Green D, McNulty D, Blumenthal MJ, Heys JR, Landvatter SW et al. 1994 A protein kinase involved in the regulation of inflammatory cytokine biosynthesis. Nature 372 739-746.

Leers-Sucheta S, Stocco DM \& Azhar S 1999 Down-regulation of steroidogenic acute regulatory (StAR) protein in rat Leydig cells: implications for regulation of testosterone production during aging. Mechanisms of Ageing and Development 107 197-203.

Lewis TS, Shapiro PS \& Ahn NG 1998 Signal transduction through MAP kinase cascades. Advances in Cancer Research 74 49-139.

Liao C, Reaven E \& Azhar S 1993 Age-related decline in the steroidogenic capacity of isolated rat Rat Leydig cells: a defect in cholesterol mobilization and processing. Journal of Steroid Biochemistry and Molecular Biology 64 39-47.

Liu J, Li H \& Padadopoulos V 2003 PAP7, a PBR/PKA-RI $\alpha$-associated protein: a new element in the relay of the hormonal induction of steroidogenesis. Journal of Steroid Biochemistry and Molecular Biology 85 275-283.

Luo L, Chen H \& Zirkin BR 2001 Leydig cell aging: steroidogenic acute regulatory protein (StAR) and cholesterol side-chain cleavage enzyme. Journal of Andrology 22 149-156.

Malamed S \& Carsia RV 1983 Aging of the rat adrenocortical cell: response to ACTH and cyclic AMP in vitro. Journal of Gerontology 38 130-136.

Manna PR \& Stocco DM 2005 Regulation of steroidogenic acute regulatory protein expression: functional and physiological consequences. Current Drug Targets. Immune, Endocrine and Metabolic Disorders 5 93-108.

Manna PR \& Stocco DM 2007 Crosstalk of CREB and Fos/Jun on a single cis-element: transcriptional repression of the steroidogenic acute regulatory protein gene. Journal of Molecular Endocrinology 39 261-277.

Manna PR, Wand XJ \& Stocco DM 2003 Involvement of multiple transcription factors in the regulation of steroidogenic acute regulatory protein gene expression. Steroids $\mathbf{6 8} 1125-1134$.

Manna PR, Eubank DW \& Stocco DM 2004 Assessment of the role of activator protein- 1 on transcription of the mouse steroidogenic acute regulatory protein gene. Molecular Endocrinology 18 558-573.

Markwell MA, Hass SM, Bieber L \& Tolbert NE 1978 A modification of the Lowry procedure to simplify protein determination in membrane and lipoprotein samples. Analytical Biochemistry 87 206-210.

Martindale JL \& Holbrook NJ 2002 Cellular response to oxidative stress: signaling for suicide and survival. Journal of Cellular Physiology 192 1-15.

Matsuzawa A \& Ichijo H 2005 Stress-responsive protein kinases in redoxregulated apoptosis signaling. Antioxidants and Redox Signaling 7 472-481.

McCubrey JA, LaHair MM \& Franklin RA 2006 Reactive oxygen speciesinduced activation of the MAP kinase signaling pathways. Antioxidants and Redox Signaling 8 1775-1789.

Medicherla R, Leers-Sucheta S, Luo Y \& Azhar S 2001 Impaired activation of AP-1 and altered expression of constitutive proteins in rat adrenal during aging. Mechanisms of Ageing and Development 122 1169-1186.

Medicherla R, Leers-Sucheta S, Luo Y \& Azhar S 2002 Age-dependent modulation of NF- $\mathrm{BB}$ expression in rat adrenal gland. Mechanisms of Ageing and Development 123 1211-1227.

Miller WL 2007 StAR search - what we know about how the steroidogenic acute regulatory protein mediates mitochondrial cholesterol import. Molecular Endocrinology 21 589-601.

Mosmann T 1983 Rapid colorimetric assay for cellular growth and survival: application to proliferation and cytotoxicity assays. Journal of Immunological Methods 65 55-63. 
Nair VD, Yuen T, Olanow CW \& Sealfon SC 2004 Early single cell bifurcation of pro- and antiapoptotic states during oxidative stress. Journal of Biological Chemistry 279 27494-27501.

Nakamura T \& Sakamoto K 2001 Reactive oxygen species up-regulates cyclooxygenase-2, p53, and Bax mRNA expression in bovine luteal cells. Biochemical and Biophysical Research Communications 284 203-210.

Papadopoulos V, Baraldi M, Guilarte TR, Knudsen TB, Lacapè J-J, Lindemann P, Norenberg MD, Nutt D, Weizman A, Zhang M-R et al. 2006 Translocator protein $(18 \mathrm{kDa})$ : new nomenclature for the peripheraltype benzodiazepine receptor based on its structure and molecular function. Trends in Pharmacological Sciences 27 402-409.

Papadopoulos V, Liu J \& Culty M 2007 Is there a mitochondrial signaling complex facilitating cholesterol import? Molecular and Cellular Endocrinology 265-266 69-64.

Pimental DR, Amin JK, Xiao L, Miller T, Viereck J, Oliver-krasinski J, Baliga R, Wang J, Siwik DA, Singh K et al. 2001 Reactive oxygen species mediate amplitude-dependent hypertrophic and apoptotic responses to mechanical stretch in cardiac myocytes. Circulation Research 89 453-460.

Popplewell PY \& Azhar S 1987 Effects of aging on cholesterol content and cholesterol-metabolizing enzymes in the rat adrenal gland. Endocrinology $12164-73$.

Popplewell PY, Tsubokawa M, Ramachandran J \& Azhar S 1986 Differential effects of aging on adrenocorticotropin receptors, adenosine $3^{\prime} 5^{\prime}-$ monophosphate response, and corticosterone secretion in adrenocortical cells from Sprague-Dawley rats. Endocrinology 119 2206-2213.

Pramanik R, Qi X, Borowicz S, Choubey D, Schultz RM, Han J \& Chen G 2003 p38 Isoforms have opposite effects on AP-1-dependent transcription through regulation of c-Jun: the determinant role of the isoforms in the MAPK signal specificity. Journal of Biological Chemistry 278 4831-4839.

Rae PA, Gutmann NS, Tsao J \& Schimmer BP 1979 Mutations in cyclic AMP-dependent protein kinase and corticotrophin (ACTH)-sensitive adenylate cyclase effect adrenal steroidogenesis. PNAS 76 1896-1900.

Raingeaud J, Whitmarsh AJ, Barrett T, Dérijard B \& Davis RJ 1996 MKK3and MKK-6 regulated gene expression is mediated by the p38 mitogenactivated protein kinase signal transduction pathway. Molecular and Cellular Biology 16 1247-1255.

Raman M, Chen W \& Cobb MH 2007 Differential regulation and properties of MAPKs. Oncogene 26 3100-3112.

Reaven E, Shi X-Y \& Azhar S 1990 Interaction of lipoproteins with isolated ovary plasma membranes. Journal of Biological Chemistry 265 19100-19111.

Schimmer BP 2000 Adrenocortical Y1 cells. Methods in Enzymology $\mathbf{5 8}$ $570-574$.

Shifren JL \& Schiff I 2000 The aging ovary. Journal of Women's Health and Gender-Based Medicine 9 (Suppl 1) S3-S7.

Stocco DM 2000 Intramitochondrial cholesterol transfer. Biochimica et Biophysica Acta 1486 184-197.

Stocco DM \& Clark BJ 1996 Regulation of the acute production of steroids in steroidogenic cells. Endocrine Reviews 17 221-244.

Tanos T, Marinissen MJ, Leskow FC, Hochbaum D, Martinetto H, Gutkind JS \& Coso OA 2005 Phosphorylation of c-Fos by Members of the p38 MAPK family: role in the AP-1 response to UV light. Journal of Biological Chemistry $28018842-18852$.

Temel RE, Trigatti B, DeMattos RB, Azhar S, Krieger M \& Williams DL 1997 Scavenger receptor calss B, type I (SR-BI) is the major route for the delivery of high density lipoprotein cholesterol to the steroidogenic pathway in cultured mouse adrenocortical cells. PNAS 94 13600-13605.

Tercyak A 1991 Determination of cholesterol and cholesterol esters. Journal of Nutritional Biochemistry 2 281-292.
Tournier C, Whitmarsh AJ, Cavanagh J, Barrett T \& Davis RJ 1999 The $M K K 7$ gene encodes a group of c-Jun $\mathrm{NH}_{2}$-terminal kinase kinases. Journal of Biological Chemistry 19 1569-1581.

Tsitouras PD, Kowatch MA \& Harman SM 1979 Age-related alterations of isolated rat Leydig cell function: gonadotropin receptors, adenosine $3^{\prime} 5^{\prime}-$ monophosphate response, and testosterone secretion. Endocrinology 105 1400-1405.

Uchida K 2000 Cellular response to bioactive lipid peroxidation products. Free Radical Research 33 731-737.

Uchida K, Shiraishi M, Naito Y, Torii Y, Nakamura Y \& Osawa T 1999 Activation of stress signaling pathways by the end product of lipid peroxidation: 4-hydroxy-2-nonenal is a potential inducer of intracellular peroxide production. Journal of Biological Chemistry $2742234-2242$.

Uchida Y, Ohba K, Yoshioka T, Irie K, Muraki T \& Maru Y 2004 Cellular carbonyl stress enhances the expression of plasminogen activator inhibitor-1 in rat white adipocytes via reactive oxygen species-dependent pathway. Journal of Biological Chemistry 279 4075-4083.

Wang X \& Stocco DM 2005 The decline in testosterone biosynthesis during male aging: a consequence of multiple alterations. Molecular and Cellular Endocrinology 238 1-7.

Wang X, Dyson MT, Jo Y \& Stocco DM 2003 Inhibition of cyclooxygenase-2 activity enhances steroidogenesis and steroidogenic acute regulatory gene expression in MA-10 mouse Leydig cells. Endocrinology 144 3368-3375.

Welch KD, Davis TZ, Van Eden ME \& Aust SD 2002 Deleterious iron-mediated oxidation of biomolecules. Free Radical Biology \& Medicine 32 $577-583$.

Whitmarsh AJ 2007 Regulation of gene transcription by mitogen-activated protein kinase signaling pathways. Biochimica et Biophysica Acta 1773 1285-1298.

Whitmarsh AJ \& Davis RJ 1996 Transcription factor AP-1 regulation by mitogen-activated protein kinase signal transduction pathways. Journal of Molecular Medicine 74 589-607.

Widmann C, Gibson S, Jarpe MB \& Johnson GL 1999 Mitogen-activated protein kinase: conservation of a three-kinase module from yeast to human. Physiological Reviews 79 143-180.

Yang T, Zhang A, Honeggar M, Kohn DE, Mizel D, Sanders K, Hoidal JR, Briggs JP \& Schnermann JB 2005 Hypertonic induction of COX-2 in collecting duct cells by reactive oxygen species of mitochondrial origin. Journal of Biological Chemistry 280 34966-34973.

Yang T, Zhang A, pasumarthy A, Zhang L, Warnock Z \& Schnermann JB 2006 Nitric oxide stimulates COX-2 expression in cultured collecting duct cells through MAP kinases and superoxide but not cGMP. American Journal of Physiology. Renal Physiology 291 F891-F895.

Zarrouki B, Soares AF, Guichardant M, Lagarde M \& Géloën A 2007 The lipid peroxidation end-product 4-HNE induces COX-2 expression through p38 MAPK activation in 3T3-L1 adipose cell. FEBS Letters $\mathbf{5 8 1}$ 2394-2400.

Zhao D, Xue H, Artemenko I \& Jefcoate C 2006 Novel signaling stimulated by arsenite increases cholesterol metabolism through increases in unphosphorylated acute regulatory (StAR) protein. Molecular and Cellular Endocrinology 231 95-107.

Zirkin BR \& Chen H 2000 Regulation of Leydig cell steroidogenic function during aging. Biology of Reproduction 63 977-981.
Received in final form 7 March 2008
Accepted 15 April 2008
Made available online as an Accepted Preprint 16 April 2008 